\title{
Egyptology Schools in Egypt during the Nineteenth Century
}

\author{
Islam Abdel Moatamed Mohamed \\ Tourist Guidance Department, Minia University
}

Enas Fares Yehia

Associate professor, Tourist Guidance Department, Minia University;

Princess Nourah Bint Abdulrahman University

Mohamed Atef Abd El-Maksoud

Professor, History Department, Faculty of Arts, Minia University

\begin{abstract}
Madrasa El Lesan Alqadeem (School of ancient language) and Madrasa Alathar Altarekheia AlMasria (the Historical Egyptian School of Archaeology) were the early Egyptology educational institutions in Egypt and established during the nineteenth century. Those schools had a Major role in graduating the first generation of the Egyptian Egyptologists and Archaeologists. Madrasa El Lesan Alqadeem graduated the Archaeological inspector Ahmed Effendi Naguib (1847-1910), as well as the Archaeologist Ahmed Kamal Pasha (1851-1923) who later contributed to establishing the Egyptology section in the Higher Teachers' School, Cairo in 1910 and 1924. Madrasa Alathar Altarekheia AlMasria graduated the great Archaeological inspectors Hassan Effendi Hosny and Mohamed Effendi Chaban (18661930). These great Archaeologists have produced a lot of Egyptology publications as well as Archaeological work.
\end{abstract}

\section{Key Words:}

Egyptology Schools, Ahmed Kamal Pasha, Ahmed Effendi Naguib, Hassan Effendi Hosny. Mohamed Effendi Chaban

\section{Introduction}

The Western scholars have rediscovered ancient Egypt during the Eighteenth and Nineteenth centuries when carrying out many archaeological excavations in Egypt then scientifically studying the discovered Antiquities as well as monuments and Artifacts.(1) Finally, their scientific production made Egyptology an academic discipline that starting at the Collège de

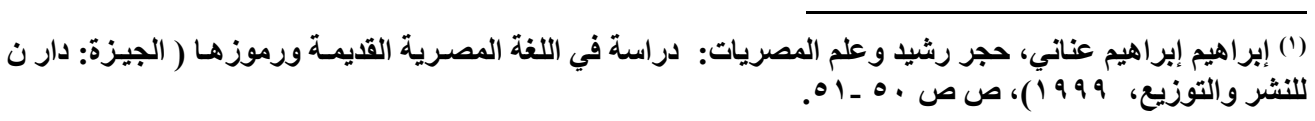


France in 1831.(2) Sheikh Rifā'ah Rāfi‘ Tạtạ̄wī, (3) considers the first nonspecialist Egyptian of Egyptology read and translate books on ancient Egypt civilization. Furthermore, he was the $1^{\text {st }}$ Egyptian write a book on the History of ancient Egypt entitles "Anwar Tawfì al-Jalīl fi Akhbar Miṣr wa-tawthìq Ban̄ Ismā ' $\bar{l} l$ " and published in Arabic in 1868. ${ }^{(4)}$ It was supposed after the establishment of the Egyptian Antiquities service and Museum in Egypt in $1858,{ }^{(5)}$ to begin establishing Egyptology Educational institutions to create Egyptian Archaeologists to participate the foreigners in administering the Archaeological institutions and later to control on the field of Egyptology in Egypt. But it achieved when Khedive Ismā'îl Pasha ordered in 1868 to teach the hieroglyphic script, and the 1st school of Egyptology, Madrasa El Lesan Alqadeem (School of the Ancient language), opened in 1869.

The alumni of Madrasa El Lesan Alqadeem did not employ after the graduation in the Egyptian Museum or the Antiquities Service. But later two of them, the Great archaeologist Ahmed Kamal Pasha became the assistant curator of the Egyptian Museum, and Ahmed Effendi Naguib, an archaeological inspector in the Antiquities service.

Madrasa Alathar Altarekheia AlMasria was established in 1881 under the request of Monsieur Gaston Maspero, the director of the Egyptian Antiquities services to graduate Egyptian Archaeological inspectors for the service. It graduated the great archaeological inspectors Mohamed Effendi Chaban and Hassan Effendi Hosny. Alī Pasha Mubārak was the 2nd non- specialist

(2) Alan Henderson Gardiner, Egypt of the Pharaohs: An Introduction (Oxford: University Press 1961), P. 17.

(3) Rifā'ah Rāfi' Tahțāwī (1801-1873) was a translator and writer, and one of the Imams of the student mission sent by Muhammad Ali Pasha to France to learn the Military arts in (1826-1831). Desiring to know his ancient civilization, He read on ancient Egypt. He also met one of the most known French Egyptologists, Sliver de Dacy by the arrangement of Edme Francois Jomard, the director of the Egyptian mission. He also translated a French book on ancient Egypt entitle "Dithyrambe Sur l'Egypte". He also translated a French book about the history of ancient Egypt on the desire of Muhammad Ali Pasha in 1838. He also sought to educate the Egyptian students on their ancient civilization, so he assigned to his students to translate books on ancient Egypt. See More on Rifā'ah Rāfi' TTahțāwī in: I.M. N. Al-Jubouri, Islamic Thought: From Mohammed to September 11, 2001 (U.S.A: Xlibris Corporation, 2010), P. 263; Donald Malcolm Reid, Whose Pharaohs?: Archaeology, Museums, and Egyptian National Identity from Napoleon to World War I (California: University Press, 2002), PP. 50-53; Adam Mestyan, Arab Patriotism: The Ideology and Culture of Power in Late Ottoman Egypt (Princeton: University Press, 2017), P. 42;

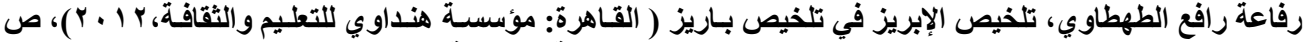

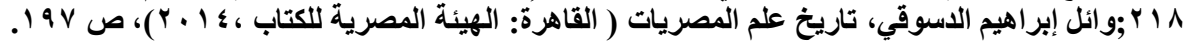

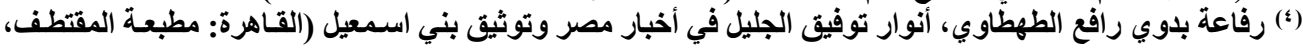

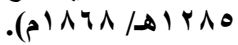

${ }^{(5)}$ Warren R. Dawson and Eric p. Uphill, who was who in Egyptology (London: the Egypt Exploration society, 3 Doughty mews, Wcin 2Pg, 1995), P. 276. 
Egyptian of Egyptology after Rifā'ah Rāfi' Tahțāwī. He also reading and writing about the ancient Egyptian civilization. ${ }^{(6)} \mathrm{He}$ wrote for the history and monuments of ancient Egypt in his known encyclopedia al- Khitat altawfiqiyah which issued between(1886-1888). ${ }^{(7)}$

\section{Madrasa El Lesan Alqadeem (1285 - 1292 A.H. / 1868-1875 A.D.)}

Khedive Isma'il issued a decree No. 1 of 13th Rajab 1285 A.H. / 1868 A.D. for determining to teach the Hieroglyphic script and Habashīyah language at Madrasa Altajhizia (a secondary school), as well as choosing the black and dark skinned students who similar to the Upper Egypt boys to join the school, in addition to appointing teachers from the Coptic Orthodox Patriarchate to teach Habashiyah in the school. ${ }^{(8)}$ According to this decree, Madrasa El Lesan Alqadeem has established as a Higher school attached to Madrasa Altajhizia and became one of the Royal schools of dīwān almadaris (the Ministry of Public Education).

(6) See on the biography of Alī Pasha Mubārak in: Okasha El Daly, Egyptology: The Missing Millennium: Ancient Egypt in Medieval Arabic Writings (New York :Routledge, 2016), P. 28; J. Brugman, An Introduction to the History of Modern Arabic Literature in Egypt ( Leiden: E. J. BRILL, 1984), PP. 65-67; Arthur Goldschmidt Jr, Historical Dictionary of Egypt (Lanham, Maryland: Scarecrow Press, 2013), P. 271;

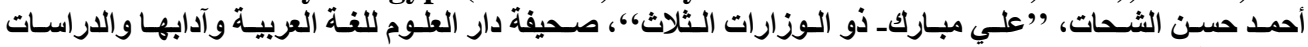

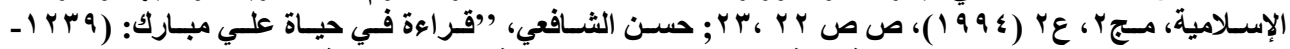

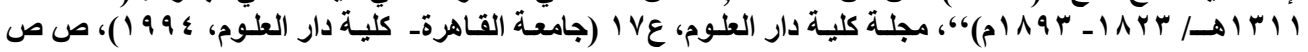
ri-ra

${ }^{(7)}$ Alī Pasha Mubārak mentions in the 7th volume of al- Khițat al-Tawfīqīyah on the foundation of Alexandria then gives a summary of the history of Egypt during the reign of Alexander the Great, and the Greco- Roman Period that Egypt was a commercial center, as well as the temples, schools and buildings have built. He also refers to the establishment of the Library of Alexandria during the reign of Ptolemy I (Lagos). He Mentions in the 8th volume on the ancient Names and Monuments of Edfu, El Ashmunein, and Akhmim, and in the 11th volume on the Monuments of Dendera. In the 13th volume on the ancient Egyptian temples at Sais, Karnak, Qurna, and Medinet Habu as well as the tombs in the Valley of the Kings, in the 14th volume on the ancient Abydos and the Ptolemaic temple in Qus, in the 15th volume on the History of Heliopolis, one of the ancient Egyptian cities, in the 16th volume on the ancient Monuments of Memphis, the pyramids and the Great Sphinx of Giza, in the 17th volume on the ancient Egyptians making offerings for their gods, and the Persians invasion of Egypt. See in:

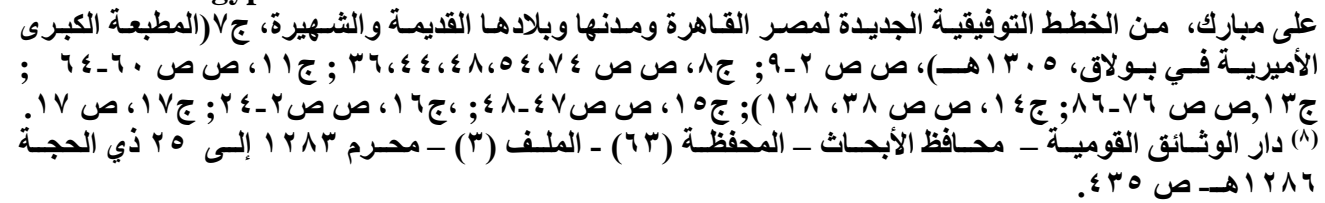

Madrasa Altajhizia was one of the secondary school established during the reign of Khedive Isma'il in Abbasia district, Cairo. See in:

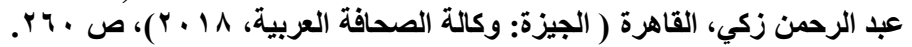


Madrasa El Lesan Alqadeem opened in 1286 A.H. / 1869 A.D., within a house at Bulaq next to Sidi Al-Qalali of dīwān almurur wal Sikat Alhadid (Diwan of Traffic and Railways). ${ }^{(9)}$ It was the first Egyptology school in Egypt sought to graduate Egyptians students know about Hieroglyphics and the civilization of Ancient Egypt to become Egyptologists for partaking in the archaeological excavations, as well as studying and preservation of the Egyptian antiquities. ${ }^{(\mathbf{1 0})}$ The school students taught about Habashīyah language which is one of the Semitic languages that appeared during the 10th century B.C. and has spoken by Ethiopians and Eritreans. ${ }^{(11)}$

The Syrian Historian Jack Tajer refers in his book" Harakat al-Tarjama bi Misr Khilal al-Qarn al-Tasa' Ashar"(The Movement of Translating in Egypt during the Nineteenth Century); that the Khedive Isma'il wanted to enroll the dark-skinned students in Madrasa El Lesan Alqadeem to become translators of Habashīyah to communicate with the inhabitance of Ethiopia after conquest their country. (12)

Heinrich Brugsch, ${ }^{(13)}$ the German Egyptologist, the 1st curator of the Egyptian Antiquities Museum in Berlin and the Honorary member of Institute de l' Egypt was chosen to be the headmaster of Madrasa El Lesan Alqadeem, ${ }^{(14)}$ to teach Hieroglyphics, and Habashīyah language. He came to Egypt in 1286AH /1869AD. (15) He signed with Ali Pasha Mubarak the Minister of Education a five-year contract with a monthly salary of 500 frank. ${ }^{(16)}$ The student of Madrasa El Lesan Alqadeem studied Hieroglyphics,

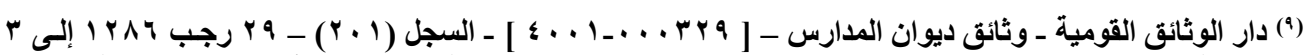

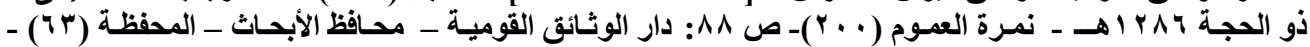

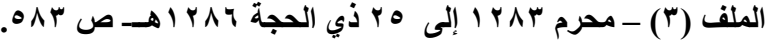

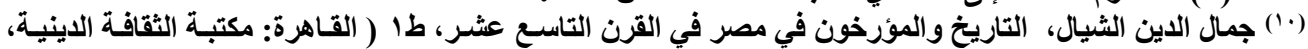

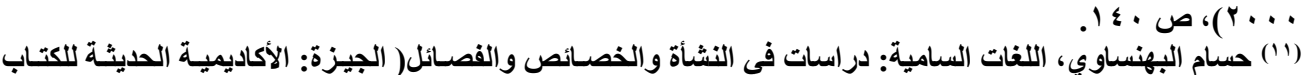

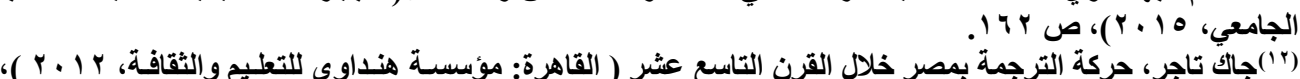

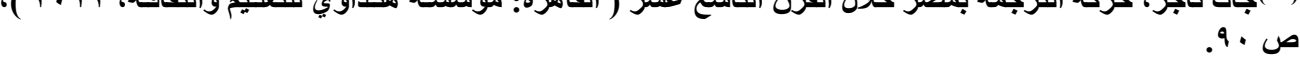

The Syrian Historian Jack Tajer (1918-1952) was a Roman Catholic born in Cairo. He was the director of the Library of Abdeen Palace. He has written several Arabic books and died after sliding his feet under the metro wheels between Cairo and Heliopolis. See in:

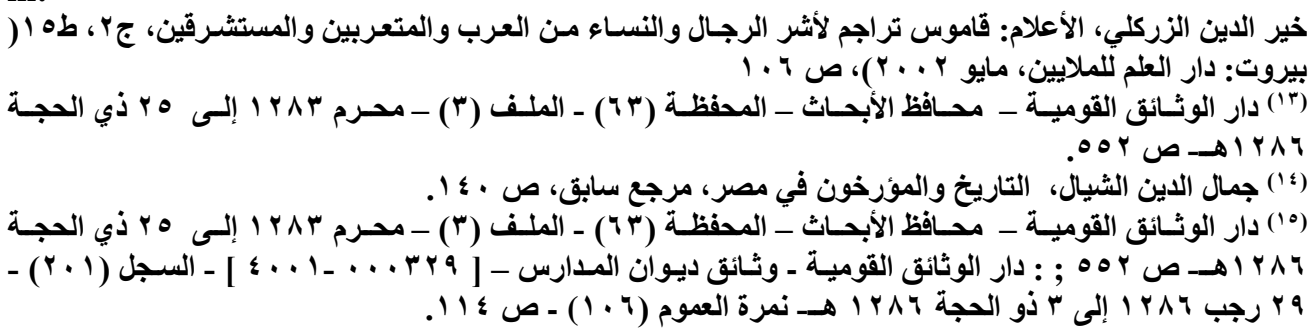

(16) Donald Malcolm Reid, Whose Pharaohs ,?, P.116. 
and Al- Habshia language, in addition to Coptic, German, ${ }^{(17)}$ and Egyptology. ${ }^{(18)}$ (Table 1)

Table 1: The subjects and Teaching staff of Madrasa El Lesan Alqadeem in (1869-1872)

\begin{tabular}{|c|c|c|c|}
\hline & Teaching Staff & Nationality & School subjects \\
\hline $\mathbf{1}$ & Heinrich Brugsch $^{(\mathbf{1 9})}$ & German & $\begin{array}{c}\text { Ancient Egyptian } \\
\text { language and History }\end{array}$ \\
\hline $\mathbf{2}$ & Emile Brugsch $^{\mathbf{2 0})}$ & German & German language \\
\hline $\mathbf{3}$ & $\begin{array}{c}\text { Mikhail Effendi } \\
\text { nazil jarjas }\end{array}$ & Egyptian & $\begin{array}{c}\text { Habashīyah and } \\
\text { Coptic language }\end{array}$ \\
\hline $\mathbf{4}$ & Sheikh Qenaoui & Egyptian & Arabic language \\
\hline
\end{tabular}

( Source:

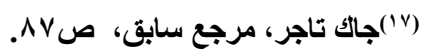

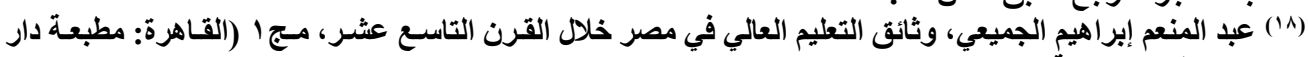

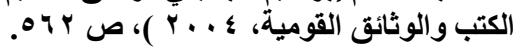

${ }^{(19)}$ Heinrich Brugsch (1827-1894), was a great German Egyptologist interested in Egyptology and Philology. He came to Egypt in 1853 as a member of a Prussia scientific Expedition sponsored by the Prussian government, and partaken the great French Egyptologist August Mariette in his excavations in Serapeum of Saqqara. He appointed as a professor of Egyptology in Berlin University and a curator of the Egyptian Museum of Berlin in 1854. He was chosen in (1864-1866) to be the counsel of Prussia in Cairo. See in: Appletons' Annual Cyclopedia and Register of Important Events of the year 1894: Embracing Political, Military,and Ecclesiastical Affairs; Public Documents; Biography ,Statistics, Commerce, Finance, Literature ,science, Agriculture, and Mechanical Industry, Vol. XIX, (New York : D. Appleton and company , 72 Fifth Avenue ,1895 ),P.610; Donald Malcolm Reid, Contesting Antiquity in Egypt: Archaeologies, Museums, and the Struggle for Identities from World War I to Nasser (Cairo: The American University Press, 2015), P. 24; Charles Henry and Stanley Davis (ed.), Biblia Devoted to Biblical Archaeology and Oriental Research, April,1892March1893 , Vol. V,( U.S.A: Meriden , conn,1893), P. 360; Sir Ernest Alfred Wallis Budge, An Egyptian Hieroglyphic Dictionary: With an Index of English words, King list of Hieroglyphic Characters, Coptic and Semitic Alphabets, Vol. I (Cosimo,2010) P. xi; M. Naville, et.al , Special Extra Report : The season's work at Ahnas and Beni Hasan , 1890-1891 , (London: Gilbert of Rivington, Limited, 1891 ), P.47.

(20) Emile Charles Albert Brugsch (1842-1930) was a German Archaeologist born in Berlin. He worked as a keeper of Antiquities under the direction of Mariette pasha in the Egyptian Museum of Bulaq. From 6-8 July1881, Emile Brugsch commissioned by Maspero the director of the Antiquities Service to survey the tomb (TT320 or DB320) at Qurnah, Thebes which is Known as a cache of el Deir el Bahri, and where he found twenty Egyptian kings' mummies. He retired in January 1914 and died in 1930. See in: Matt Cardin, Mummies around the World: An Encyclopedia of Mummies in History, Religion, and Popular Culture: An Encyclopedia of Mummies in History, Religion, and Popular Culture (Santa Barbara, California: ABC-CLIO, 2015), PP. 42, 43; Sue H. D' Auria(ed.),Servant of Mut: studies in Honor of Richard A. Fazzini (Boston, Leiden : Brill, 2008), P. 112. 


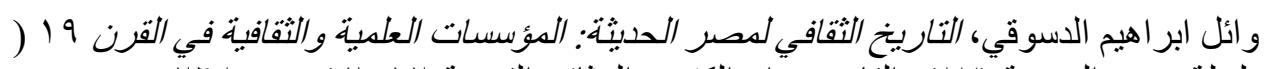

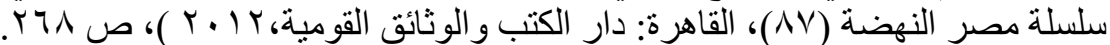

Initially, on $14^{\text {th }}$ Shawwal 1286 A.H./ 1869A.D., five students were selected from the Higher schools, Madrasa al'iidara (the school of management) and Madrasa Al-Masaha wal al Mohasaba (school of accounting) to join Madrasa El Lesan Alqadeem, (Table 2).

Table2: Names of the $1^{\text {st }}$ five students enrolled in Madrasa El Lesan Alqadeem.

\begin{tabular}{|c|c|c|}
\hline & Student Name & Previous School \\
\hline 1 & Ahmed Naguib & Madrasa al'iidara \\
\hline 2 & Ali Jayid & Madrasa Al-Masaha wal al Mohasaba \\
\hline 3 & Mohamed Tawfik & Madrasa al'iidara \\
\hline 4 & Mohamed Esmat & Madrasa Al-Masaha wal al Mohasaba \\
\hline 5 & Mohamed Fakhry & Madrasa Al-Masaha wal al Mohasaba \\
\hline
\end{tabular}

(Source:

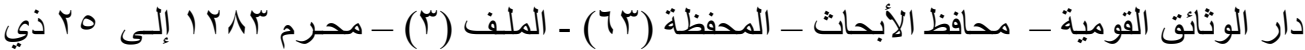

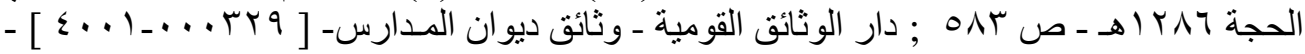

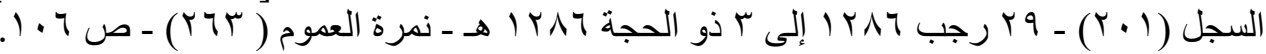

On $20^{\text {th }}$ Shawwal 1286 A.H./ 1869A.D., other five students enrolled in Madrasa El Lesan Alqadeem (Table3).

Table3: Names of the other five students enrolled in Madrasa EI Lesan Alqadeem

\begin{tabular}{|l|c|c|}
\hline & Student Name & Previous School \\
\hline 1 & Ahmed Hassan & Madrasa Altajhizia \\
\hline 2 & Ahmed Kamal & Madrasa Altajhizia \\
\hline 3 & Ibrahim Naguib & Madrasa Altajhizia \\
\hline 4 & Hussein Zaki & Madrasa Altajhizia \\
\hline 5 & Mohammed Wasfi & Madrasa Altajhizia \\
\hline
\end{tabular}

(Source:

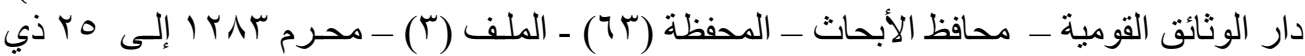

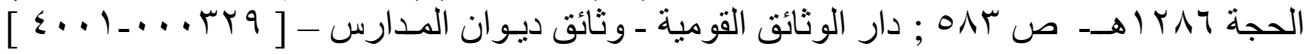

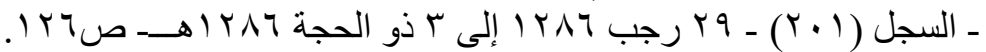

The Students of Madrasa El Lesan Alqadeem were going on field trips to the Monuments of Upper Egypt and the Egyptian Museum. ${ }^{(21)}$ They have

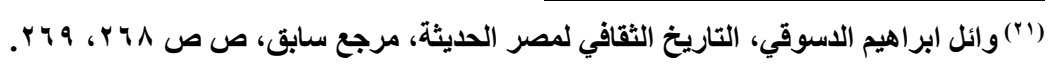
The magazine of Rawdat Almadaris established in 1287 A.H./ 1870 A.D. by Ali pasha Mubarak the Minister of Education and Rifā'ah Rāfi' Țahțāwī the teacher of Madrasa al'iidara we al-Alsun. It considered the first scientific cultural magazine in Egypt. It was Bimonthly Magazine and under supervises of dīwān almadaris (the Ministry of Public Education). Various articles and translated books were published in the 
translated the articles of Heinrich Brugsch, in Arabic then published it in the magazine of Rawdat Almadaris such as Hussein Zaky Effendi, ${ }^{(22)}$ and Mohamed Effendi Tawfiq. ${ }^{(23)}$ It was chosen a representative from the Coptic Patriarchs in Egypt to test the students of Madrasa El Lesan Alqadeem on Hieroglyphic and Habashia language at Darab aljamamiz, Cairo. ${ }^{(24)}$ The budget of Madrasa El Lesan Alqadeem was followed the Ministry of Finance. (25) On 14 Shawwal 1286A.H./ 1869, it was determined for the 1st five students joined the school a monthly pocket money of 50 piasters to each student, as well as, teaching tools, clothes, chef and also daily sum of 4 piasters to provide the food to each student. On 17 Shawwal 1286 A.H. / 1869 A.D., Madrasa El Lesan Alqadeem supplied with a ship to visit the Egyptian monuments and led by Ahmad Radwan Al-Saqqa with a monthly salary of 125 piasters. (26) After the students of Madrasa El Lesan Alqadeem became ten students, their monthly pocket money decreased from 50 to 25 piasters except Mohammad Effendi Wasafi became 40 piasters. (Table 4)

The German Archaeologist Emile Brugsch (1842-1930), came to Egypt in 1870 to teach with his brother, Heinrich Brugsch at Madrasa El Lesan Alqadeem. ${ }^{(27)}$ On 4th Shawwal 1288A.H./1871 A.D., dīwān almadaris decided to move the residence of Madrasa El Lesan Alqadeem to the Schools Complex at Durb Al-Jamamiz, Due to the complaint of Heinrich Brugsch, on the humidity in the school and the House. ${ }^{(28)}$ In the same year, Muhammad Effendi Tawfiq, a student of Madrasa El Lesan Alqadeem had employed as an assistant at Diwan Makatib al'ahlia (the Diwan of the Civil offices), and a teacher of German at Alexandria. ${ }^{(29)}$ But he sicked and left work to come back to the school to complete his study. ${ }^{(30)}$ The budged of Madrasa El Lesan

magazine by students and the professors of Egyptian schools in Poetry, History, Literature, Geography, Sociology and etc. See in:

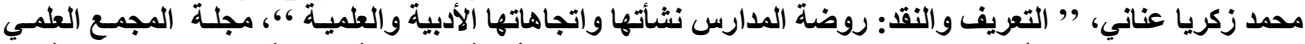

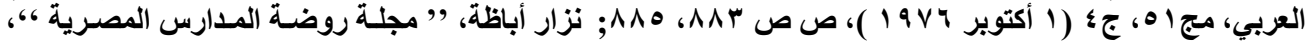

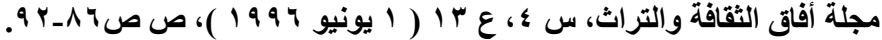

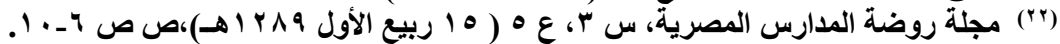

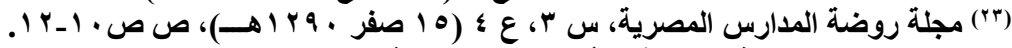

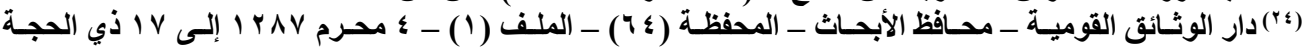

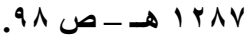

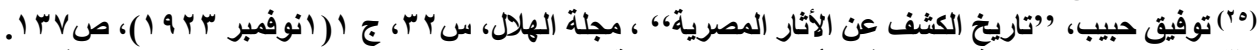

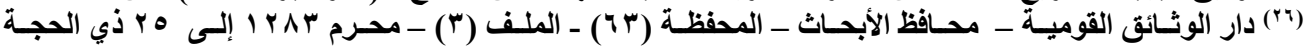

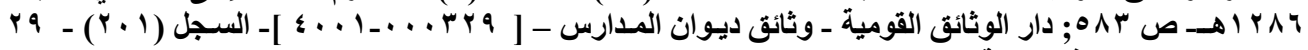

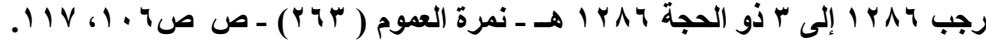

(27) Matt Cardin, Op. Cit., PP. 42, 43.

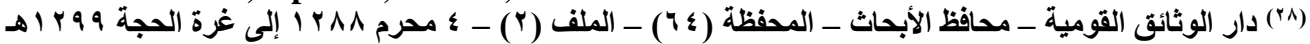

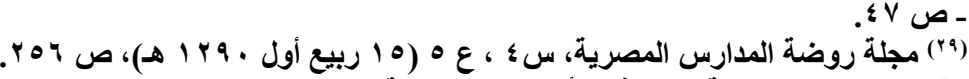

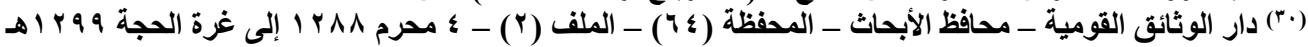


Alqadeem in (1871-1872 ) was as follows; 1009E.P for the salaries of three teachers and 112 E.P for sending a student from the school in a student mission outside of Egypt. ${ }^{(31)}$

Table 4: The Expenses Statement of seven students of Madrasa EI Lesan Alqadeem in 1289A.H./ 1872 A.D

\begin{tabular}{|l|c|c|c|c|}
\hline & Student Name & $\begin{array}{c}\text { The Monthly } \\
\text { pocket money } \\
\text { (Pias.) }\end{array}$ & $\begin{array}{c}\text { The Clothes } \\
\text { costs (Pias.) }\end{array}$ & $\begin{array}{c}\text { The Monthly } \\
\text { Food costs } \\
\text { (Pias.) }\end{array}$ \\
\hline $\mathbf{1}$ & Ahmed Hassan & 25 & $32 / 6$ & 120 \\
\hline $\mathbf{2}$ & Ahmad Kamal & 25 & $32 / 6$ & 120 \\
\hline $\mathbf{3}$ & Ibrahim Naguib & 25 & $32 / 6$ & 120 \\
\hline $\mathbf{4}$ & Hussein Zaki & 25 & $32 / 6$ & 120 \\
\hline $\mathbf{5}$ & Mohamed Esmat & 25 & $32 / 6$ & 120 \\
\hline $\mathbf{6}$ & $\begin{array}{c}\text { Mohamed } \\
\text { Fakhry }\end{array}$ & 25 & $32 / 6$ & 120 \\
\hline $\mathbf{7}$ & Mohamed wasfi & 40 & $32 / 6$ & 120 \\
\hline
\end{tabular}

(Source:

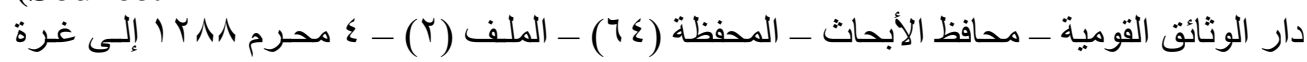

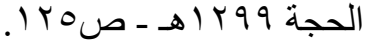

In 1289 A.H. / 1872 A.D., it had planned to teach German in the Egyptian schools but to Bring teachers from abroad were going to cost a lot of money. So on 17th Shaaban 1289 A.H./ 1872 A.D., it decided to send five students of Madrasa El Lesan Alqadeem to Austria or Prussia with Monsieur Heinrich Brugsch to stay for a year or half-year to learn German at one of the schools there. It determined to each student a monthly sum of 300 Frank for clothes, house's rent and food costs, as well as teachers' salaries. After their return were going to appoint as teachers of German at the Royal schools, ${ }^{(32)}$ unfortunately, this not achieved. ${ }^{(33)}$

Monsieur Heinrich Brugsch tried to catch the Graduates of Madrasa El Lesan Alqadeem at the Egyptian Museum, but Mariette Pasha, the director of the Egyptian Antiquities service and the Egyptian Museum, refused. So the school alumni appointed by order of Khedive Ismail as teachers of German in Amiri (government) Schools. ${ }^{(34)}$ The refusal of Mariette Pasha to hire the alumni of Madrasa El Lesan Alqadeem in the Egyptian Archaeological

(31) Donald Malcolm Reid, Whose Pharaohs,? Op. Cit., P.116.

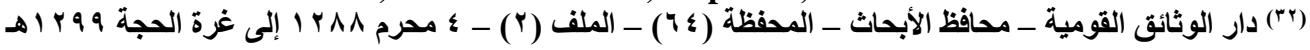

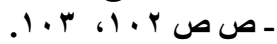

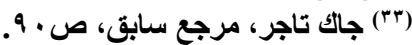

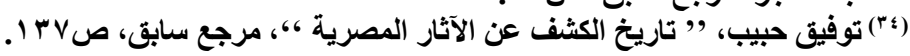


institution may explain for the bad report of the Swiss inspector of schools Dor Bey in 1872; that the school students not qualified to work in the Egyptian Museum and they suitable for guarding the museum. ${ }^{(35)}$ Another possibility is that Mariette Pasha exploited the bad report for that he didn't want to give the opportunity for the Egyptians to control on the archaeological institutions, which may effect on the European administration on the field of Archeology in Egypt. Because of their knowledge of Habashiyah, French and German, the Egyptian government ordered in 1289 A.H. / 1872 A.D. to employee seven students of Madrasa El Lesan Alqadeem, as assistants and translators at Diwan Makatib al'ahlia (the Diwan of the Civil offices) and supplying each one with Monthly salary of 400 piasters. (Table5) and only three students were remaining to learn at the school. They were Ahmed Naguib Ali Jayid Mohamed Tawfik. Emile Brugsch left Madrasa El Lesan Alqadeem in 1872 to join the Egyptian Museum. (36)

Table 5: The Government occupations held by the seven alumni of Madrasa El Lesan Alqadeem in 1289 A.H. / 1872 A.D.

\begin{tabular}{|c|c|c|}
\hline & Graduates Names & The Government occupations \\
\hline 1 & $\begin{array}{l}\text { Ahmed Hassan } \\
\text { Effendi }\end{array}$ & $\begin{array}{c}\text { Assistant at Diwan Makatib al'ahlia, and } \\
\text { Teacher of French at Madrasa El Lesan } \\
\text { Alqadeem }\end{array}$ \\
\hline 2 & $\begin{array}{l}\text { Ahmad Kamal } \\
\text { Effendi }\end{array}$ & $\begin{array}{c}\text { Assistant at Diwan Makatib al'ahlia, and } \\
\text { Teacher of French, German and math at } \\
\text { Madrasa Mobtadyan }\end{array}$ \\
\hline 3 & $\begin{array}{l}\text { Ibrahim Naguib } \\
\text { Effendi }\end{array}$ & $\begin{array}{l}\text { Assistant at Diwan Makatib al'ahlia and } \\
\text { Teacher of French and math at Madrasa } \\
\text { Mobtadyan }\end{array}$ \\
\hline 4 & $\begin{array}{l}\text { Hussein Zaki } \\
\text { Effendi }\end{array}$ & $\begin{array}{l}\text { Assistant at Diwan Makatib al'ahlia, Teacher of } \\
\text { French and math at Madrasa Mobtadyan, and } \\
\text { German at Madras El Lesan Alqadeem }\end{array}$ \\
\hline 5 & $\begin{array}{l}\text { Mohamed Esmat } \\
\text { Effendi }\end{array}$ & $\begin{array}{l}\text { Assistant at Diwan Makatib al'ahlia, and } \\
\text { Teacher of French at Madrasa Altajhizia }\end{array}$ \\
\hline 6 & $\begin{array}{l}\text { Mohamed Fakhry } \\
\text { Effendi }\end{array}$ & $\begin{array}{l}\text { Assistant at Diwan Makatib al'ahlia, Teacher of } \\
\text { German and math at Madrasa Mobtadyan and } \\
\text { Hieroglyphic at Madrasa El Lesan Alqadeem }\end{array}$ \\
\hline 7 & $\begin{array}{l}\text { Mohamed wasfi } \\
\text { Effendi }\end{array}$ & $\begin{array}{l}\text { Assistant at Diwan Makatib al'ahlia, Teacher of } \\
\text { Turkish at Madrasa Mobtadyan and German at } \\
\text { Madrasa Altajhizia }\end{array}$ \\
\hline
\end{tabular}

(Source:

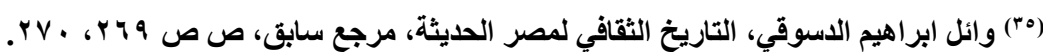

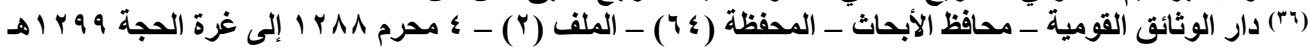

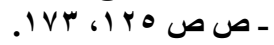




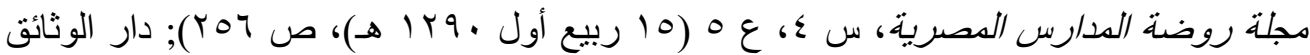

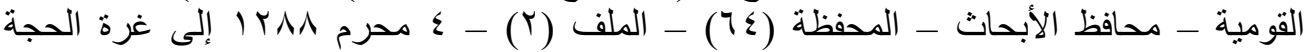

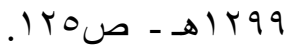

The teaching staff of Madrasa El Lesan Alqadeem became five in 1873,(37) included Heinrich Brugsch and Mikhail Effendi Nazil Gerges, as well as three of the school graduates, Ahmed Hassan Effendi, as the teacher of French, Hussein Zaki Effendi as the teacher of Germany, and Mohamed Fakhry Effendi as the teacher of hieroglyphic. ${ }^{(38)}$ Heinrich Brugsch represented Egypt in several scientific Exhibition of Antiquities such as of Vienna in $1873,{ }^{(39)}$ as a result, he apologized to continue teaching at Madrasa El Lesan Alqadeem in 1874. So dīwān almadaris decided to appoint the remaining students of the school in the Telegraph of the Railway in 1874. Mikhail Effendi Nazil Gerges, the teacher of Habashiyah was the last teachers remind to teach at Madrasa El Lesan Alqadeem until its cancellation in 1875. (40) Despite the European domination on the field of Egyptology in Egypt, ${ }^{(\mathbf{4})}$ and the rejection of Mariette Pasha to appoint the alumni of Madras El Lesan Alqadeem at the Egyptian Museum, ${ }^{\mathbf{( 4 2})}$ later, two of the school graduates, Ahmed Effendi Naguib and Ahmad Kamal Pasha caught Archaeological jobs.

\section{Ahmed kamal pasha (1851-1923)}

The great Egyptian Archaeologist Ahmed Ibn Hassan Ibn Ahmed who well known as Ahmed Kamal, ${ }^{(43)}$ graduated from Madrasa El Lesan Alqadeem in 1289 A.H./1872A.D. He employed as an assistant at Diwan Makatib al'ahlia, and teacher of French, German and math at Mubtadian School. ${ }^{(44)}$ Then he joined other jobs such as an assistant and a translator at the Ministry of Education. ${ }^{(45)}$ On 29 November 1881, Ahmed Kamal employed as a

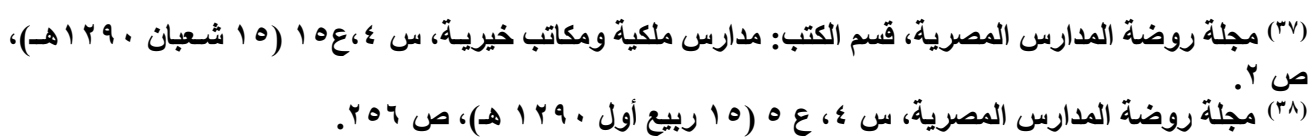

${ }^{(39)}$ Royal Asiatic Society of Great Britain and Ireland, Journal of the Royal Asiatic Society of Great Britain and Ireland (Cambridge: University Press for the Royal Asiatic Society,1895), P.462.

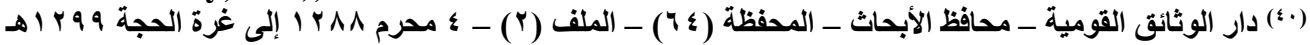

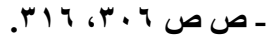

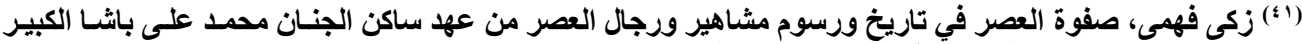

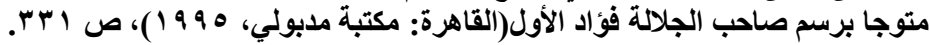

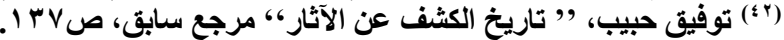

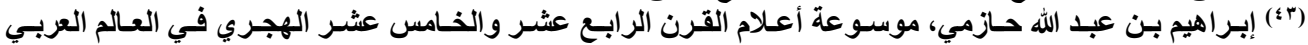

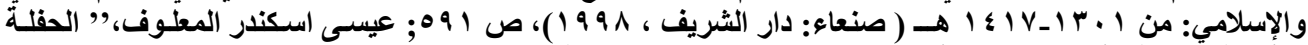

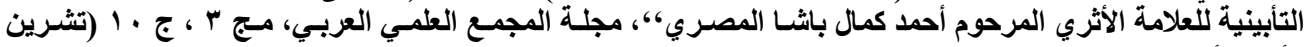

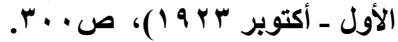

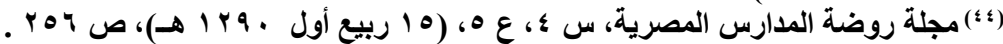

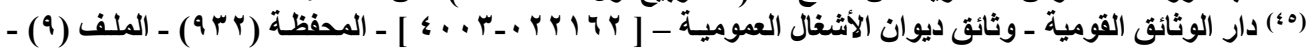

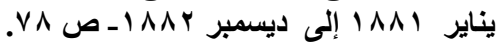


secretary-translator at Bulaq Museum by order of Prime Minister Riyad Pasha. (46) in 1881, Ahmed Kamal became the director and the teacher of Egyptology at Madrasa Alathar Altarekheia AlMasria.(47) Ahmed Kamal promoted to be as an assistant curator in the Egyptian Museum in 1891, (48) and continued until his retiring in 1914. ${ }^{(49)}$ He gave lectures on Ancient Egypt history on the Higher School Club, in (1906-1908), and at the private Egyptian University in 1908-1909. ${ }^{(50)}$ He chose to be the director of the Egyptology section of Madrasa al-Mu'allimin alkhadiwia (the Khedival Teachers' School) on $1^{\text {st }}$ October 1910 and also to teach Egyptology with an annual salary of 200 pounds. ${ }^{(51)}$

In 1910 Ahmed Kemal Pasha called to establish regional museums in Egypt, which began to be founding in 1913. ${ }^{(52)}$ In August 1923 he has chosen to teach Egyptology at the Higher Teachers' School, but he died. ${ }^{(53)}$ He wrote more than 29 articles in French as reports on his excavations and published it in ASAE. ${ }^{\text {(54) }}$ He excavated at many archaeological sites in Upper, Middle and Lower Egypt such as: In 1900 he carried out excavations at the village of Hiba which situates to the north of Markas Al-Fashn, Beni Suef. $\mathrm{He}$ found the ruins of the village door, a height of six $\mathrm{m}$ locates at the Northern wall and refers "that the walls of the village which used as a fortress against the attacks of the desert Bedouins". One of the village ruins still also exists is a ruins of a temple constructed by King Shoshenq I, 22nd dynasty to worship the god Amen-Re. He also surveyed the ancient Roman necropolis at Tell Al-Hiba. After seven days of surveying, he discovered some terracotta

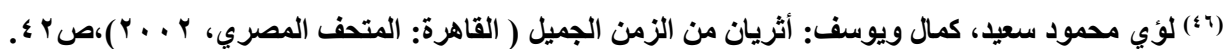

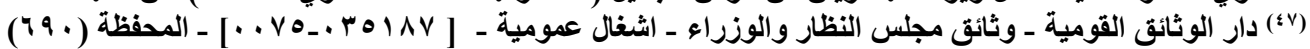

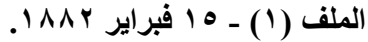

(48) Shadia Mahmoud, The development of Archaeological and Historical Museums in Egypt during the Nineteenth and twentieth centuries: Imperialism, Nationalism, Unesco Patronage, and Egyptian Museology Today (published PhD thesis ), the Graduate Faculty of Texas Tech University, 2012, P. 96.

${ }^{(49)}$ Sally MacDonald, and Michael Rice, Consuming Ancient Egypt (California: Left Coast Press, 2003), P. 125.

${ }^{(50)}$ Donald Malcolm Reid, Contesting Antiquity in Egypt, Op .Cit.,P. 203.

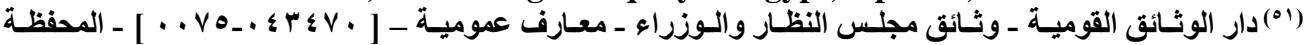

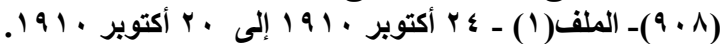

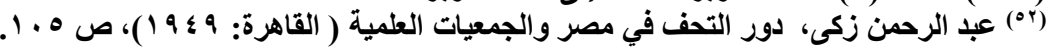

(53) Donald M. Reid, "Indigenous Egyptology: The Decolonization of a Profession?," Journal of the American Oriental Society, Vol. 105, No. 2 (Apr. - Jun., 1985), P. 241.

${ }^{(54)}$ Jill Kamil , Labib Habachi: The Life and legacy of an Egyptologist ( Cairo: American University Press, 2007), PP.28,21; See the Archaeological sites which excavated by Ahmed Kamal Pasha in:

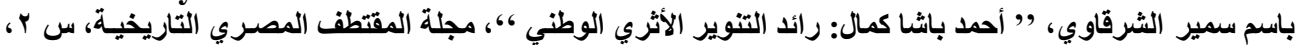


vases, six Canopic jars bearing the name of god Douamoutef in Hieratic and wooden panel. ${ }^{(55)}$

On 4th March 1900, Ahmad Kamal Pasha began excavating east of Deir al-Barsha, Mallawi where there is a Necropolis contain many tombs dating back to the 11th and 12th Dynasties, Middle Kingdom. Some of these tombs carved into the mountain and the other built of bricks. The direction of these tombs is to the north-west of the Nile valley. He discovered seven burial shafts, and in four of them was a collection of funerary furniture, such as an alabaster vase, an enamelled bronze semicircular vase, a terracotta vase, a rest of wooden chair, and fragments of a wooden box, limestone and wooden heads of Canopic jars. He also found another burial shaft led to discovering the tomb of Amenemhat, one of the governors of El-Ashmunein province, Middle Kingdom. The shaft of his Tomb was at a depth of seven meters contained ten slabs, wooden Canopic lid as well as, panels seemed removed from two Sarcophagi of Amenemhat. Ahmed Kamal Pasha describes the tomb of Amenemhat that it is a vaulted tomb Consists of a burial chamber for two wooden sarcophagi in various sized. There are hieroglyphics inscriptions in black ink are decorated the large sarcophagus.

He found on the cover of the large sarcophagi a group of funerary boats, as well as, statuettes of sailors and paddlers. He discovered two cedar wood statuettes of Amenemhat, one of them was wholly damaged and the other a well -preserved; its height of $37 \mathrm{~cm}$, depends on a black pedestal and represents Amenemhat standing, wearing a Shendyt kilt, and holding vases in his hand. He found on the burial chamber several objects such as some cedar wood statuettes, pottery vessel, limestone offering tables, a wooden statuette of Horus, Urseus, a wooden handle, a long dagger, a knife, vases, and remains of a wooden bed.

On 16th March 1900, Ahmed Kamal discovered another burial shaft; about five meters from the shaft tomb of Amenemhat. It led to the discovery of three vaulted tombs:

The 1st tomb was a burial of a Female called - $\Gamma$ - in which Ahmed Kamal Pasha discovered a large coffin decorates with hieroglyphic inscriptions. He also found a collection of funerary furniture on the burial chamber such as pottery pot, and two wooden female statuettes, one a wellpreserved represents a female with an inlaid eye, curly hair, wearing a dress adorned with lotus flowers. The other statuette almost damaged, and is representing a dwarf woman with rough hands and missing legs. The 2nd tomb was also a burial of a Female; contain neck of a female's mummy, and collection of funerary furniture such as pottery, a pot and vases.

${ }^{(55)}$ Ahmed Bey Kamal, 'Description générale des ruines de Hibé, de son temple et de sa nécropole, "ASAE 2 (1901), PP. 85-91. 
The 3rd tomb was a burial of a female called

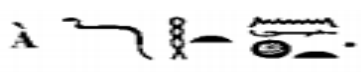

in which Ahmed Kamal found a coffin of a female called L 14 , and he noted that the tomb owner usurped the coffin which reused three times. He also found the sarcophagus of the owner with rest of hieroglyphic inscriptions in blue, and a wooden statuette representing a female standing on a pedestal, as well as a collection of funerary objects such as wooden boats, wooden statuettes of sailors, and an Alabaster Canopic lid. $\mathrm{He}$ also discovered another burial shaft contains a collection of wooden statuettes of sailors, as well as, a broken hawk's head, which formed an end of a necklace. This shaft led Ahmed Kamal Pasha to discover other three tombs; the most prominent was the burial of Nhry Ashmunein province, Middle Kingdom. Ahmed Kamal Pasha found two coffins and the mummy of the tomb owner as well as, several objects such as a collection of wooden funerary boats, and some females' statuettes standing on pedestals and carrying offering vases. ${ }^{(56)}$

In January and February 1901, Ahmed Kamal Pasha returned to excavate at Deir Al Barsha where surveyed thirty vaulted tombs of the princes of Ashmunein. He discovered many funerary objects such as large and small terracotta, Pottery, bronze, Alabaster, rounded and spherical vases, as well as a limestone offering table, and canopic Jars in the form of the four sons of god Horus. He also found two wooden sarcophagi scripted by funerary spells well known as the coffins texts which help the dead on their journey to the afterlife. (57) In 1902 for the third time, Ahmed Kamal excavated at Deir Al Barsha specifically in the northern hill, and his remarkable discovery was an Alabaster offering table which found at an entrance of one of the tombs there. $\mathrm{He}$ also excavated in the southeast of Deir al-Barsha in a cemetery locates at the south of Darb-Zebeida where he discovered a limestone statue of a scarab and small baboons statues in a squatting position. ${ }^{(\mathbf{5 8})} \mathrm{He}$ has written books and articles in Arabic and French on various subjects, ${ }^{(59)}$ on the ancient Egypt history, Archaeology, and Hieroglyphics, ${ }^{(60)}$ in addition to creating

(56) Ahmed Bey kamal, “Fouilles à Deir-el-Barsheh (mars-avril 1900)", ASAE2 (1901), PP. 14-43.

(57) Ahmed Bey Kamal, “'Rapport sur les fouilles exécutées à Deir-el-Barshé, en janvier, février, mars 1901”, ASAE2 (1901), PP. 206-222.

(58) Ahmed Bey Kamal, “Fouilles à Deir-el-Barché exécutées dans les six premiers mois de l'année par M. Antonini de Mallawi ", ASAE3(1902), PP.276 - 282.

(59) Sally MacDonald, and Michael Rice, Op. Cit., P. 125 .

(60) Zahi Hawass, Hidden Treasures Of The Egyptian Museum: On Hundred Masterpieces From The Centennial Exhibition (Cairo: American University Press, 2002), P. xxix. 
two volumes for the Egyptian museum catalogue, and published many Articles in ASAE. ${ }^{(61)}$

\section{Ahmed Effendi Naguib (1847-1910)}

Ahmed Effendi Naguib was one of the alumni of Madrasa El Lesan Alqadeem, and in 1882, he appointed as a teacher of History in the Amiry schools. ${ }^{(62)}$ Between (1892 -1899), ${ }^{(63)}$ he employed as a general inspector in the Antiquities service. He wrote reports on the some discovered Antiquities such as, of de Morgen and also published several articles in French in ASAE on his Excavations. ${ }^{(64)}$

On 27th April 1902, He was commissioned by the Antiquities service to write a report on the discovery of fragments of a statue of king Seti II which found in a house in the southeast of a village in Adfih. On 8th May 1902, he wrote his report in French, mentioned that the fragments of the statue discovered with some lime stones are inscribed in Hieroglyphic seems as of sanctuary used for worshipping the ancient deities, Isis, Hathor and Aphrodite. Unfortunately, the stones destroyed because it used to build the house and the statue only sent to the Egyptian museum. He referred that the statue made of sandstone, the lower part of the statue, a Height of $61 \mathrm{~cm}$ base on Rectangular pedestal. It represents King Seti II is kneeling, wearing striped Shendyt kilt and holding Naos with carved images of Isis, Hathor and Aphrodite and there is on the pedestal a cartouche of the titles and names of the King inscribed in hieroglyphics. ${ }^{(65)}$

In 1903, a person called Ahmed Abdel-Nabi noticed a statue lying on the ground and surrounded by two men about $2 \mathrm{~km}$ from the village of Zaidia near Osim, west of Giza. He suspected in those men who were talking on the value of it. He quickly informed the Mayor of Zaidia who could capture the statue then reported the Antiquities service which immediately sent Ahmed Naguib to get the statue. Ahmed Naguib examined and wrote a report on the statue; that it is made of granite, a height of $41 \mathrm{~cm}$. It represents a tigress or lioness in Squatting position, directs her head to her small child, a height of $11 \mathrm{~cm}$ and length of $30 \mathrm{~cm}$, whose mouth towards his mother's thigh. There is damage in the tigress or lioness's mouth and the claws of the north palm too. The statue does not contain any inscriptions and is in rough carving. It refers

(61) Donald Malcolm Reid, Contesting Antiquity in Egypt, Op. Cit., P. 32.

${ }^{(62)}$ Donald Malcolm Reid, Whose Pharaohs,? Op. Cit., P.189.

(63) Margarita diaz- Andreu , A world history of nineteenth century Archaeology: Nationalism ,colonialism, and the past, (Oxford: University Press, 2007), P.124.

(64) Donald Malcolm Reid, Whose Pharaoh?, Op. Cit., PP. 202,203.

(65) Ahmed Effendi Naguib, "Sur un fragment de statue de Séti II trouvé à Atfih ", ASAE 3 (1902), PP.213-214. 
that it returns to a non-prosperity period in Egypt. ${ }^{(66)}$ In 1906, Ahmed Naguib discovered a shaft leads to a pipe, $30 \mathrm{~cm}$ high in Kom Nakhla Bahria. Unfortunately, it was impossible for Ahmed Najib to enter and inspect the pipe because it blocked by mud. ${ }^{(67)}$ In 1899 , He commissioned by the antiquities service to descriptive the caves of Gabel Tura and Al Maasra .${ }^{(68)} \mathrm{He}$ retired and left the Egyptian Antiquities service in 1905 as a result of a dangerous illness, ${ }^{(69)}$ then he decided to become a journalist and issued a journal named AL- Mandhoum. ${ }^{(70)}$ After a struggle with the disease, he died in 1910. ${ }^{(71)}$

\section{Madrasa Alathar Altarekheia AlMasria (1881-1886)}

The Ministry of public works approved the suggestion of M. Maspero, the General Director of the Egyptian Antiquities service to establish an Egyptology school affiliate to the Egyptian Museum. ${ }^{(72)}$ It also saw that necessary teaching Egyptians about their ancestors' ancient language and Antiquities. ${ }^{(73)}$ On $16^{\text {th }}$ October 1881, the Ministry of public works and Monsieur Maspero, the director of Antikhana (Egyptian Museum) had presented a note to the council of Ministry to add five hundred Egyptian pounds to the budget of Antiquities service to be the annual budget of the Egyptology school. He decided to choose a few students to enroll the Egyptology school. He also planned to appoint the school graduates at the Egyptian Antiquities service. ${ }^{(74)}$ Indeed, Sheriff Pasha the Prime Minister, ${ }^{(75)}$ decided on $30^{\text {th }}$ October 1881 adding five hundred Egyptian pounds to the budget of the Antiquities service of 1882 to be the annual budget of the Egyptology school. ${ }^{(76)}$ ( Table 6)

(66) Ahmed Naguib, "'Rapport sur une statue de tigresse ou de lionne trouvée à Oussim ", ASAE 4 (1903), PP. 83 - 84.

(67) Ahmed Naguib, "une conduite d'eau à Kom el-Nakhla ", ASAE 7 (1906), PP. 95-96 .

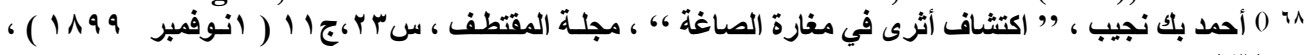

${ }^{(69)}$ Warren R. Dawson and Eric P. Uphill , Op. Cit., P.306.

${ }^{(70)}$ Gamal El-Din El-Shayyal , A history of Egyptian Historiography in the nineteenth century ( Faculty of Arts , N.15, Alexandria, 1962), P.59.

(71) Warren R. Dawson and Eric P. Uphill ,Op. Cit., P.306.

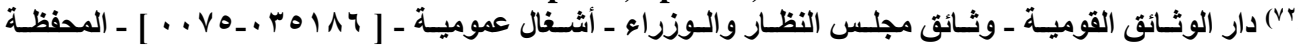

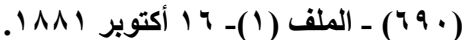

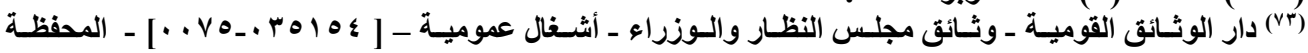

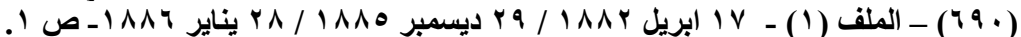

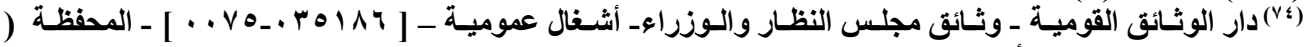

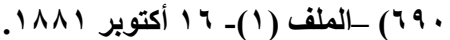

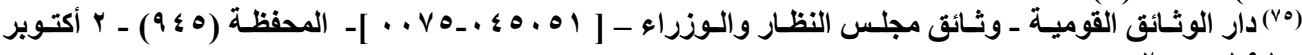

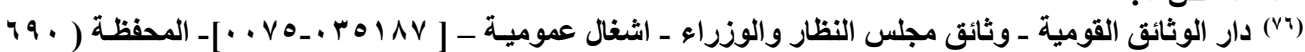

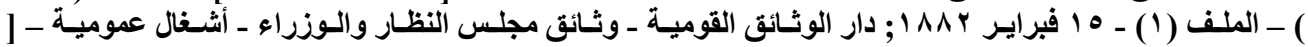


Table 6: The Budget of 1882 for teaching five students at Madrasa Alathar Altarekheia AlMasria

\begin{tabular}{|l|c|c|}
\hline & Requirements & Amounts( pias) \\
\hline $\mathbf{1}$ & A salary of teacher of Egyptology, French, and \\
history & 800 \\
\hline $\mathbf{2}$ & A salary of a Geography and Math teacher & 500 \\
\hline $\mathbf{3}$ & A salary of a teacher of Arabic & 400 \\
\hline $\mathbf{4}$ & A salary of a chef & 200 \\
\hline $\mathbf{5}$ & A salary of a doorman & 125 \\
\hline $\mathbf{6}$ & A salary of a garden man & 200 \\
\hline $\mathbf{7}$ & Monthly salaries of 15 piasters for every & 75 \\
\hline $\mathbf{8}$ & student & 60 \\
\hline $\mathbf{9}$ & Teaching tools & 200 \\
\hline $\mathbf{1 0}$ & A monthly house fee & 900 \\
\hline $\mathbf{1 1}$ & Food & 3360 \\
\hline $\mathbf{1 2}$ & Gross per month & 40220 \\
\hline $\mathbf{1 3}$ & An addition amount for buying clothes in the & 2000 \\
\hline $\mathbf{1 4}$ & year & 2000 \\
\hline $\mathbf{1 5}$ & Textbooks & 2000 \\
\hline $\mathbf{1 6}$ & Beds and mattresses & 3780 \\
\hline & A reserve amount & 50000 Pias /500£E \\
\hline
\end{tabular}

\section{(Source:}

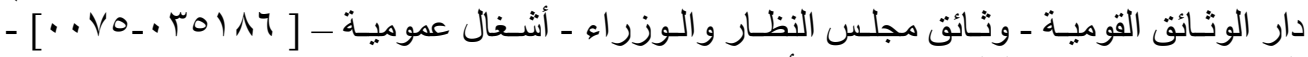

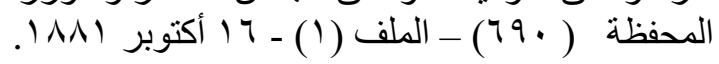

Maspero had rented a house with Monthly leasing contract in front of the Egyptian Museum to be the residence of Madrasa Alathar Altarekheia AlMasria. Initially, it was specified $62 £ \mathrm{E}$ and 60 Pias to buy the school supplies. Maspero ordered Ahmed Effendi Kamal, the translator in the Egyptian Museum to choose five students and must be from the middle class even not resigning from the antiquities service owing to the fewer salaries. (Table 7)

The Egyptian Museum requested on 28 December 1881 to open Madrasa Alathar Altarekheia AlMasria at the beginning of January 1882. ${ }^{(77)}$

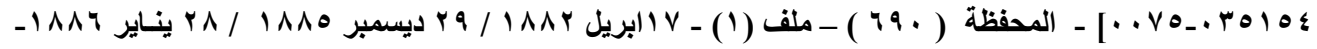

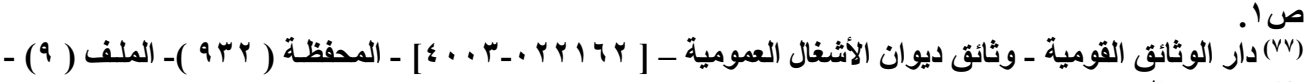

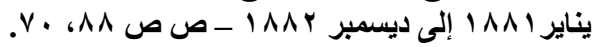


Table 7: Names of the $1^{\text {st }}$ five students chose to enroll Madrasa Alathar Altarekheia AlMasria in 26 December 1881.

\begin{tabular}{|l|c|c|}
\hline & Student Name & Previous School \\
\hline $\mathbf{1}$ & Abdul al-Rahman Fahmy & Madrasa Mobtadyan \\
\hline $\mathbf{2}$ & Ahmed Naguib & $\begin{array}{c}\text { Madrasa Altajhizia (a secondary } \\
\text { School) }\end{array}$ \\
\hline $\mathbf{3}$ & Hassan Hosny & Madrasa Al-Khugat \\
\hline $\mathbf{4}$ & Mohamed Chaban & The British missionary \\
\hline $\mathbf{5}$ & Mahmoud Hamdi & Madrasa Al-Khugat \\
\hline
\end{tabular}

(Source:

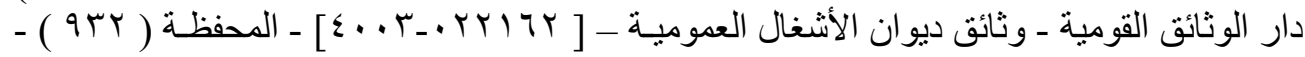

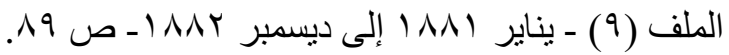

In addition to the five students, had found that necessary to add other ten, and some of them should be Copts because they have a good knowledge of the Coptic language, and it becomes easy for them learning hieroglyphics. On 17th April 1882, the Minister of public works sent a Statement of Expenses of the fifteen students to the council of ministry (Table 8).

Table 8: The Budget of $\mathbf{1 8 8 2}$ for teaching fifteen students at Madrasa Alathar Altarekheia AlMasria

\begin{tabular}{|c|c|c|}
\hline $\mathbf{1}$ & Requirements & Amounts(Pias) \\
\hline & $\begin{array}{c}\text { A salary of Ahmed Effendi Kamal, the } \\
\text { Headmaster and teacher of Egyptology, } \\
\text { French and history. }\end{array}$ & 800 \\
\hline $\mathbf{2}$ & A salary of a teacher of Arabic. & 300 \\
\hline $\mathbf{3}$ & A salary of a Geography and Math teacher. & 400 \\
\hline $\mathbf{4}$ & A salary of a teacher of the art. & 500 \\
\hline $\mathbf{5}$ & A salary of a teacher of the Handwriting. & 200 \\
\hline $\mathbf{6}$ & A salary of a sorter. & 200 \\
\hline $\mathbf{7}$ & A salary of a Gardener. & 200 \\
\hline $\mathbf{8}$ & A salary of a Doorman. & 150 \\
\hline $\mathbf{9}$ & Students' monthly salaries of 15 piasters for & 225 \\
\hline $\mathbf{1 0}$ & every student. & 180 \\
\hline $\mathbf{1 1}$ & Teaching tools & 20 \\
\hline $\mathbf{1 2}$ & Toilet paper. & 800 \\
\hline $\mathbf{1 3}$ & A monthly house fee. & 2700 \\
\hline $\mathbf{1 4}$ & food, soap, and shaving. & 6675 \\
\hline $\mathbf{1 5}$ & The Gross per month. & 80100 \\
\hline $\mathbf{1 6}$ & The total in the year. & 6000 \\
\hline
\end{tabular}


By: Faculty of Tourism and Hotels, Minia University

\begin{tabular}{|c|c|c|}
\hline $\mathbf{1 7}$ & $\begin{array}{c}\text { Beds and mattresses, blankets, and bed } \\
\text { sheets. }\end{array}$ & 6000 \\
\hline $\mathbf{1 8}$ & Dining room tools. & 2500 \\
\hline $\mathbf{1 9}$ & Clothes & 6000 \\
\hline $\mathbf{2 0}$ & A reserve amount. & 4000 \\
\hline & The annual aggregate amount. & 104600 Pias / 1,046£E \\
\hline
\end{tabular}

\section{(Source:}

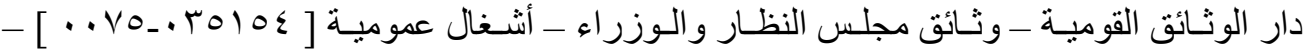

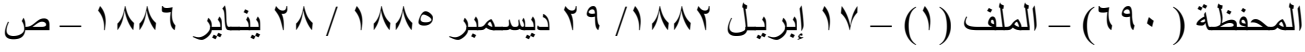

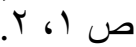

Table 9: The salaries of the Teaching Staff of Madrasa Alathar Altarekheia AlMasria

\begin{tabular}{|c|c|c|c|}
\hline $\mathbf{1}$ & Teaching Staff & Subject & Salary (Pias) \\
\hline $\mathbf{2}$ & $\begin{array}{c}\text { Sheikh Mohammed } \\
\text { Diab }\end{array}$ & $\begin{array}{c}\text { Headmaster and teacher } \\
\text { of Egyptology }\end{array}$ & 800 \\
\hline $\mathbf{3}$ & $\begin{array}{c}\text { Ibrahim Effendi } \\
\text { Hussein }\end{array}$ & Handwriting teacher & 300 \\
\hline $\mathbf{4}$ & Khalifa Effendi Hassan & Math teacher. & 500 \\
\hline
\end{tabular}

(Source:

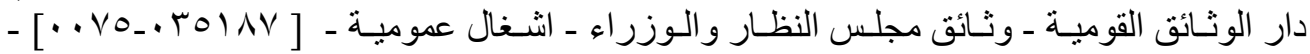

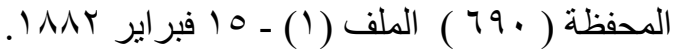

Maspero had requested to appoint Khalifa Hassan as the geography teacher and the bookkeeper with monthly salary of 1500 piasters Plus the 500 piasters of his salary as the teacher of Math at Madrasa Alathar Altarekheia AlMasria. ${ }^{(78)}$ It determined in the budget of the Antiquities service of 1885 that only six alumni of Madrasa Alathar Altarekheia AlMasria would appoint as third-degree Archaeological inspectors with annual salaries of 60 Egyptian pounds for each one. They were Diab Tamsah, Ahmed Naguib, Mahmoud Hamdi, Abdel Rahman Fahmy, Hassan Hosni, and Mohammed Chaban. But on $12^{\text {th }}$ November 1885 , the budget had been revised with adding other five graduates of the school to employ as second- degree Archaeological inspectors with annual salaries of 90 Egyptian pounds for each one. They were Ali Effendi Habib, Ahmed Effendi Yahia, Mohamed Effendi Marzouk, Thaddeus Mfufban, and Ahmad Effendi Thabit. Thus eleven graduates of the

(VA)

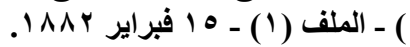


school appointed as archaeological inspectors in $1886 .{ }^{(79)}$ Unfortunately, later Eugene Grebaut (1886-1892) the director of the Antiquities service dismissed them. ${ }^{(80)}$ Except three; Mohamed Effendi Chaban and Hassan Effendi Hosni who later get promoted to be a first-degree archaeological inspectors and Mohamed Effendi Fred who became as an account manager of the Antiquities Service. ${ }^{(81)}$

On $29^{\text {th }}$ December 1885, the Minister of public works sent a note to the council of Ministry requesting to cancel the school under the request of Monsieur Maspero's, the director of the Egyptian Museum who reported to the ministry of public works that the students after four years had finished their study at Madrasa Alathar Altarekheia Almasria and they were going to appoint as inspectors at the Archaeological sites. He found the amounts reported in the budget of 1886 of the Antiquities service didn't be allowed to increase the number of Archaeological inspectors. Therefore, he demanded to cancel the school and using its Expenses as salaries for the new jobs in the Ministry of public works. Especially, it established temporarily and was agreed to cancel after the students end their study. ${ }^{(\mathbf{8 2})}$ On $4^{\text {th }}$ January 1886 , the Ministry of public works sent a note to the Finance Committee of the Ministry for cancelling Madrasa Alathar Altarekheia. ${ }^{(83)}$ On 10th January 1886, Finance Committee of Ministry of public works sent the cancellation note of the school to be ratified by the Prime Minister, ${ }^{(\mathbf{8 4})}$ and indeed, it cancelled in July $1886 .{ }^{\left(\mathbf{8 5}^{5}\right.}$

\section{Hassan Effendi Hosny}

Hassan Effendi Hosny was one of the alumni of Madrasa Alathar Altarekheia AlMasria and appointed as an archaeological inspector in the Egyptian Antiquities service in 1886. He participated in many excavations and led others such as on 4th February 1898, when he was the Archaeological inspector of Qurna, he participated Monsieur Victor Loret, the DirectorGeneral of the Antiquities Service, on his excavation at Biban Al-muluk,

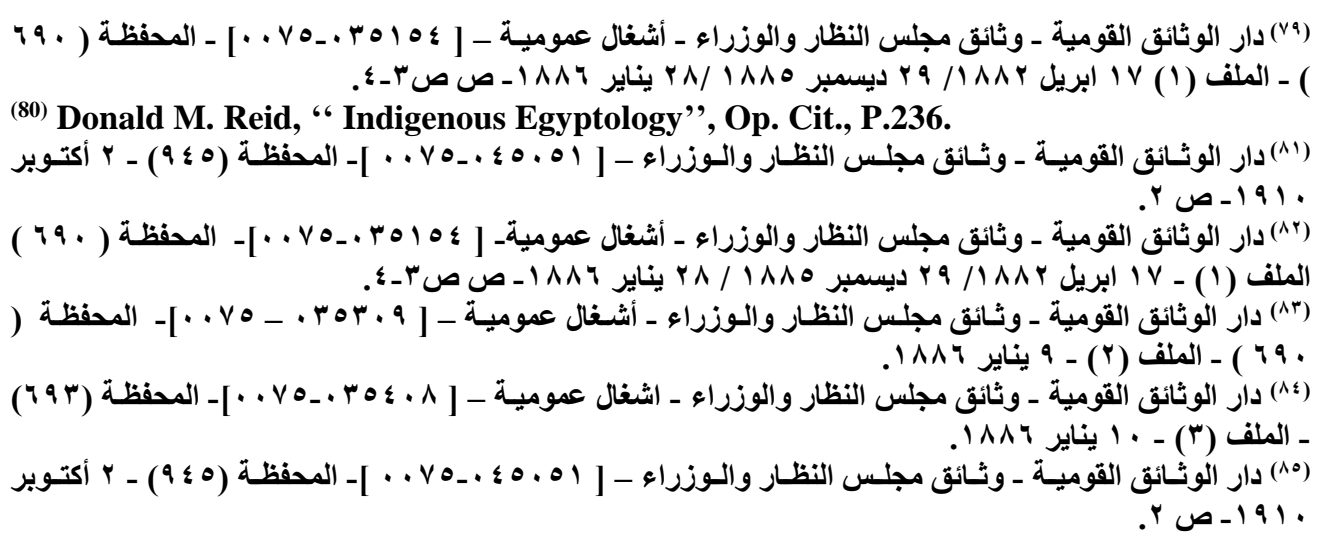


Luxor that is also known as the Valley of the Kings and contains a collection of Egyptian kings tombs of New Kingdom. On 8th February 1898, Monsieur Victor Loret went to Aswan leaving Hassan Effendi Hosny to complete the excavation who led to the discovery of the tomb KV34 of King Thutmose III, 18th Dynasty.The tomb found carved in rock and situated about 250 meters from the tomb of King Ramses III, Immediately, Hassan Effendi Hosni sent a telegraph to Monsieur Victor Loret to report him on this great discovery. Monsieur Victor Loret returned to Luxor and surveyed the discovered tomb. (86)

In 1903 Hassan Effendi Hosny, as the Archaeological inspector of Luxor surveyed a tomb discovered by the inhabitants of El Kola, north of Nag ElIwadat, Kouft, Qena governorate. The Antiquities Service had commissioned Him to write a report on the tomb. He described it; that contains an underground limestone burial chamber decorated with an inscription in the red colour. He found sandstone Stela inscribed in demotic at the entrance of the burial chamber. He found inside the burial chamber two sarcophagi; one of them made of grey granite in the shape of human mummy and decorated

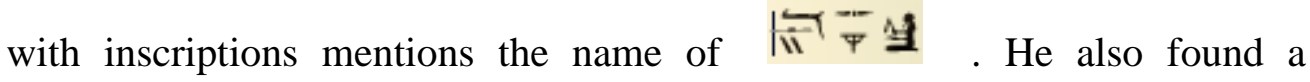
limestone amulet in the form of a scarab, as well as, a limestone Stela decorated with a scene shows the tomb owner presenting an offering to several deities such as Isis, Osiris, Atom, Hermachis and followed by hieroglyphic inscriptions with the name of the tomb owner. ${ }^{(87)}$

On 26th December 1903, George Legrain the great archaeologist discovered the cache of Karnak, which contained many statues and stele. ${ }^{(88)}$ In 1904, Hassan Effendi Hosny participated George Legrain in the excavation at Karnak. ${ }^{(89)}$ The results were the discovery of a collection of wooden objects such as statues, furniture and chests. ${ }^{(90)}$ In 1905 Hassan Effendi Hosny, the Archaeological inspector of Luxor played a distinguished role in urging the antiquities thieves for recovering of the looted antiquities of Karnak. He succeeded in arresting one of the antiquities dealers at Luxor who

(86) Victor Loret, les tombeaux de thoutmès III et d'Amènophis II: et la cacheite royale de Biban - el- Molouk ( le Cairo Imprimerie Nationale, 1899), PP. 3,4,7.

(87) Howard carter," Report on General work done in the southern inspectorate", ASAE 4 (1903), PP.49-50.

(88) The Egyptian Supreme Council of Antiquities and the French Institute of Oriental Archaeology, The Cachette of Karnak: A Research Project on Georges Legrain's Discoveries between 1903 and 1907, P. 3. www.ifao.egnet.net/bases/cachette.

(89) Gouvernement Égyptien, Rapports Sur La Marche Du service des Antiquites de 1899 à 1910 ( Le Caire Imprimerie Nationale ,1912), P. 122.

(90) The Egyptian Supreme Council of Antiquities, Op. Cit., P. 10. 
called Abdel Hakim Shehata. ${ }^{(91)}$ In August 1907 Hassan Effendi Hosny became the Archaeological inspector of Giza. ${ }^{(92)}$

On 8th April 1908, Hassan Effendi Hosni participated Mr.Dow Covington in surveying a cemetery extends $1.5 \mathrm{~km}$ west of wady el Kittar, about $28 \mathrm{~km}$ to Atfieh and east of the pyramid of Seneferu at Medium. The cemetery contains several grave tombs, as well as burials which contained female and male's adult's bodies without the head and feet. There he discovered a fragment of potsherds, of a small jar, and a small figure represents goddess Nephthys. ${ }^{(93)}$ In 1909 Hassan Effendi Hosny excavated at the village of Mit Rahina, El-Badrashin, Giza where he found statuettes date back to the GrecoRoman period. ${ }^{(94)}$ On 10th May 1911, he excavated at the mountain of ElKena, to the east of Atfih, where discovered thirty-two pits seemed as burial shafts. He dug only twelve and found all were empty except one contained a skeleton. ${ }^{(95)}$

\section{Mohamed Effendi Chaban (1866- 1930)}

Mohamed Effendi Chaban was one of the alumni of Madrasa Alathar Altarekheia AlMasria and became an Archaeological inspector in various provinces of Upper Egypt and Lower Egypt. In 1916, he promoted to be Assistant Curator in the Egyptian Museum and was the second Egyptian held this position after Ahmed Kamal Pasha, the great Archaeologist. (96) $\mathrm{He}$ excavated many sits such as in 1899 he excavated at the village of ElKhawaled, Assiut where there is a Necropolis date back to the 19th Dynasty and hides beneath a modern cemetery. An underground tomb was observed by one of the village's natives while burying a member of his relatives, so Mohamed Effendi Chaban went to open and survey it. His results were; that it was a burial of a high official known as Souti $\neq$ " who was a prominent person closed to the king Seti I and the responsible his royal treasury.

Muhammad Effendi Chaban describes the tomb of Souti as follow; there is a shaft that leads to it. There is an inscription on the lintel and Jambs of the tomb entrance. It consists of a hypostyle hall supported by six limestone pillars. There are engraved religious inscriptions in honour of god Osiris on the left wall of the Hypostyle Hall. The tomb contains several chambers; one

(91) Gouvernement Égyptien, Op. Cit., PP.171, 174 .

(92) Ibid , P.228.

(93) Mr. Dow Covington, "Report on A summary exploration of Wady El kittar", ASAE 9 (1908), PP .98, 102, 103, 104.

(94) Gouvernement Égyptien, OP. Cit. P.294.

(95) Hassan Effendi Hosni, 'Rapport sur une fouille Exècutèe dans le Desert Arabique àL' Est d'Atfih', ASAE 12 (1912), P. 56.

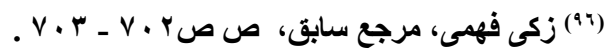


of which used for the mummy of Souti who found in a broken black granite coffin decorated with inscriptions. The lid of Souti 's coffin found in the shaft of the tomb and was decorated with images of the God Osiris, and God Anubis as well as other various gods following by hieroglyphic inscriptions. $\mathrm{He}$ found one of the tomb chambers leads to a vault consisting of a corridor, and the other chambers contained bones, as well as, a Mummy skeleton and alabaster Canopic jar. ${ }^{(97)}$

In 1902, one of the farmers of Qusayr El-Amarna, Assiut discovered an entrance led to a tomb, immediately the Antiquities service commissioned Mohamed Effendi Chaban to excavate there. His excavation led to the discovery of two tombs carved in rock to the east of Jabal Abu al-Fida and dating back to the 6th Dynasty, Old Kingdom. He reported on the first tomb;

that was a burial of a High official known as

Khu-n-wkh. The tomb entrance to the east leads to a burial chamber, a length of $3 \mathrm{~m} .90 \mathrm{~cm}$ and a wide of $1 \mathrm{~m} .65 \mathrm{~cm}$, Its wall decorates with a daily life and religious rituals scenes. On the right of the eastern wall of the burial chamber; there are several representations of the tomb owner in various positions such as he appears walking in a garden and holding flowers or standing on a fishing boat and hunting fish and the tomb owner represents in front of Gazelle. There is on the southern wall a niche which a hollow area to put a life-size statue of the tomb owner which carved in rock and represents the Khu-n-wkh standing and wearing a Shendyt kilt and bracelets. On the southern wall of the burial chamber; there is a representation of Khu-n-wkh sitting in front of a table with few flowers followed by inscriptions giving his name and titles. There is also a procession accompanied by women are standing and holding a list of offerings. Another scene represents the tomb owner and his wife sitting to each other. The scenes on the Western Wall of the burial chamber; there is a view of the false door bears the name and titles of the tomb owner. Mohamed Effendi Chaban mentioned that there is a burial shaft in the tomb used to rebury other dead and found it filled with mummies dating back to the Roman period. Many of jewels of these mummies stole. $\mathrm{He}$ also found some bones and fruit and terracotta vases.

The second tomb discovered by Mohamed Effendi Chaban; was a burial of the prince of Pepi-ankh the eldest, 굴 4 who was one of the sons of King Pepi I, 6th dynasty, Old Kingdom. It situates to the north of the tomb of Khu-n-wkh. It consists of a pillared vestibule supporting by two Pillars decorated with hieroglyphs inscriptions and to the south of it, there is a burial chamber. In the middle of the southern wall of the hall, there

(97) Mohammed Effendi Chabân," Un tombeau de la XIX dynastie à El-Khawaled ", ASAE 2 (1902), PP. 137 - 140. 
is a depiction of an offering table, and on the western wall of it, a representation of false door contains a view of Pepi-ankh the eldest as well as, his wife and his son following by hieroglyphic inscriptions. There is a burial shaft, a deep of $14 \mathrm{~m}$ in the tomb used to bury the mummy of tomb owner and his family to put away from the thieves. Mohamed Effendi Chaban found a collection of furniture, as well as, statuettes, which almost destroyed. ${ }^{(98)}$

In 1901, Mohamed Effendi Chaban began an archaeological survey at the ruins of the ancient city of El-Ashmunein (Hermopolis Magna), where he found remains of a temple date back to the 19th Dynasty, New kingdom. The temple built by King Merneptah and completed by his son King Seti Merneptah who well known as Seti II. He reported on the temple as follow; that only the pylon of the temple is still existing and consists of two towers, one of which is a less height and the other a Height of $8 \mathrm{~m}$, adorned by offering scenes making to the god Amen, as well as, god Thoth, the main deity of Hermopolis Magna. There also ruins of the inner part of the temple which is the nine columns of the Hypostyle Hall. He found to the south of the pylon of the temple of King Merneptah and Seti II, ruins of another pylon date back to the Roman period, as well as, ruins of a chapel returned to the reign of king Amenemhat II, 12th dynasty, Middle Kingdom. He also found ruins of a temple of King Ramses II, and the bases of columns as well as the rest of the temple walls and, a colossal statue at the entrance of the temple; its upper part destroyed and represents King Ramses II. ${ }^{(99)}$ In 1911 Mohamed Effendi Chaban was commissioned to survey a cemetery date back to the Greco-Roman period which locates opposite the village of Qantara, distant $500 \mathrm{~m}$ to the Suez Canal, and to the east of the Tell of Abu Saif. Its length of $3 \mathrm{~km}$ and contains a group of tombs built of red brick and some of it is vaulted. He found more than 19 sarcophagi limestone, Terracotta coffins; a few of it decorated with inscriptions, and their lids have broken as well as, a few of mummies well-preserved in addition to corrupt bones. He also found a collection of Ushabti statues and statuettes of various deities, as well as, amulets depicted Apis bull, the god Thoth, and the god Horus. ${ }^{(\mathbf{1 0 0})}$

\section{Conclusion}

In 1285 A.H. /1868A.D, Khedive Ismā'īl Pasha has ordered to establish the 1st Egyptology school in Egypt, Madrasa El Lesan Alqadeem (School of

(98) Mohammed Effendi Chabân " Sur une nécropole de la VI ${ }^{\mathrm{e}}$ dynastie, à Koçeir elAmarna: Rapport de Mohammed effendi Chabân', ASAE 3 (1902), PP. 250 - 254.

(99) Mohammed Effendi Chabân, “ Fouilles à Achmounéîn ", ASAE 8 (1907), PP. 211 223.

(100) Mohammed Effendi Chabân, " Fouilles exécutées près d'El-Kantara ", ASAE 12 (1912) ,PP. 69 - 75. 
the Ancient language), which opened at Bulaq, Cairo in 1869 under the administration of dīwān almadaris. It followed until its cancellation to Madrasa Altajhizia, one of the secondary school established during the reign of Khedive Ismā $\overline{1}$ l. Its Budget had affiliated to the Ministry of Finance. Its students provided with monthly pocket money of 25 piasters, and a ship led by Ahmad Radwan Al-Saqqa, with a monthly salary of 125 piasters, as well as House, Chef, food, teaching tools, and clothes. They did not send at student Missions abroad or appoint after graduation in the Egyptian Museum and the Egyptian Antiquities service. Almost of the school students graduated in 1872 as teachers of French, Germany, Turkish and Math in the Egyptian government schools. The remaining of the school alumni chose to join the school teaching staff. They were Ahmed Hassan Effendi, as the teacher of French, Hussein Zaki Effendi as the teacher of Germany, and Mohamed Fakhry Effendi as the teacher of hieroglyphic. The German Egyptologist Heinrich Brugsch taught at Madrasa El Lesan Alqadeem in (1869-1873) and the German Archaeologist Emile Brugsch from 1870 to 1872. Later, two of the alumni of Madrasa El Lesan Alqadeem has appointed in the archaeological field. They were Ahmed Kamal pasha who became the assistant curator of the Egyptian museum in 1891 and Ahmed Naguib Effendi as the Archaeological inspector in the Antiquities service in 1892. For the apology of Heinrich Brugsch to continue as the teacher and the director of Madrasa El Lesan Alqadeem in 1874, dīwān almadaris decided to appoint the remaining students of the school in the Telegraph of the Railway, and Mikhail Effendi Nazil, the teacher of Habashiyah was the last teachers remind to teach at Madrasa El Lesan Alqadeem until its cancellation in 1875.

Madrasa Alathar Altarekheia AlMasria was the $2^{\text {nd }}$ Egyptology school in Egypt. It had affiliated to Antikhana (Egyptian Museum), established in 1881 and opened in 1882. The annual budget of Madrasa Alathar Altarekheia AlMasria was 50000 Pias /500£E and increased to 104600 pias / 1,046£E. Fifteen students enrolled in the school and taught math, Arabic, handwriting and Egyptology. When Ahmed Kamal pasha was a translator in the Egyptian Museum, he chose to be the director and the teacher of Egyptology of Madrasa Alathar Altarekheia AlMasria. At the end of 1885, eleven alumni of Madrasa Alathar Altarekheia AlMasria appointed as archaeological inspectors, and Most of them dismissed by Eugene Grebaut, the director of the Antiquities service in (1886-1892). Except three, Mohamed Effendi Chaban and Hassan Effendi Hosni who later get promoted to be a first-degree archaeological inspector as well as Mohamed Effendi Fred who became as an account manager of the Antiquities Service. Madrasa Alathar Altarekheia AlMasria cancelled in July 1886 because of the budget of 1886 of the Antiquities service didn't be allowed to increase the number of the Archaeological inspectors. 


\section{Bibliography}

\section{A- Unpublished documents}

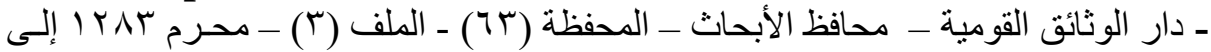

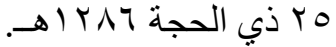

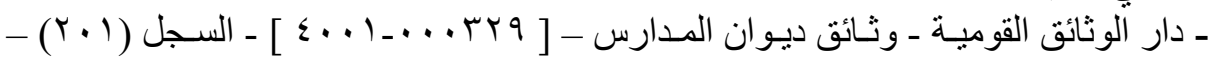

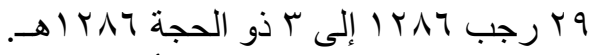

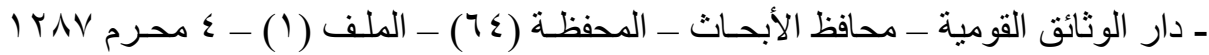

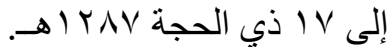

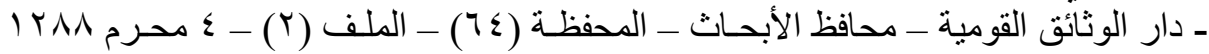

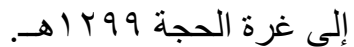

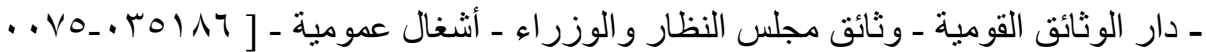

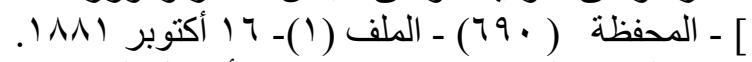

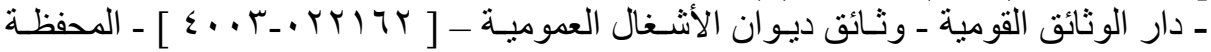

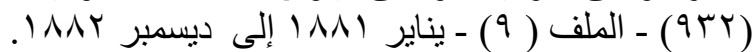

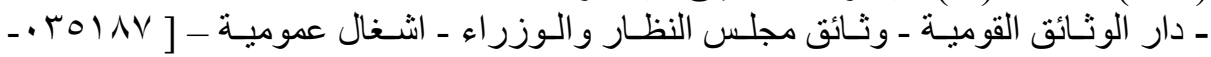

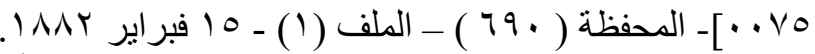

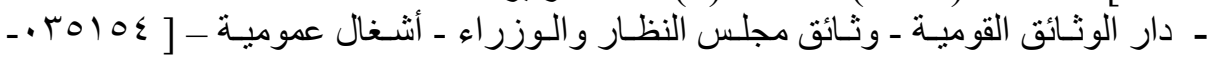

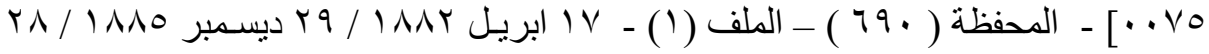

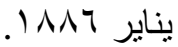

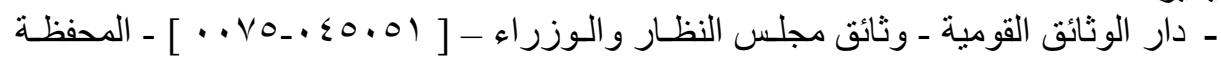

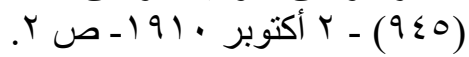

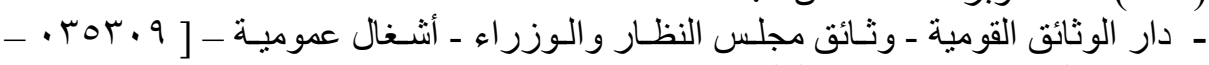

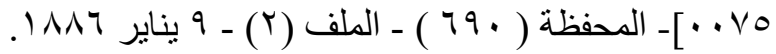

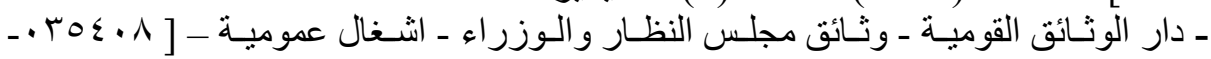

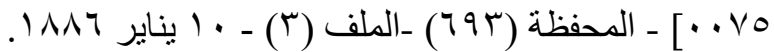

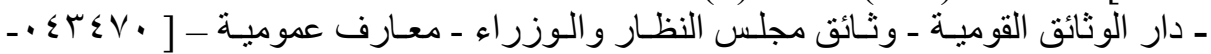

\section{b- Periodicals}

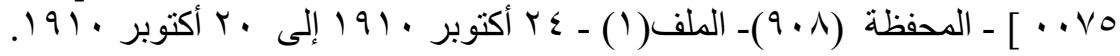

- Ahmed Bey Kamal, “'Description générale des ruines de Hibé, de son temple et de sa nécropole, '”ASAE 2 (1901), PP. 85-91.

- 1900)",ASAE2 (1901), PP. 14-43.

- Barshé, en janvier, février, mars 1901", ASAE2 (1901), PP. 206-222.

"Fouilles à Deir-el-Barché exécutées dans les six premiers mois de l'année par M. Antonini de Mallawi ', ASAE3(1902), PP.276 - 282.

- Ahmed Effendi Naguib, "Sur un fragment de statue de Séti II trouvé à Atfih ', ASAE 3 (1902), PP.213-214. 
trouvée à Oussim ", ASAE 4 (1903), PP. $83-84$.

"une conduite d'eau à Kom el-Nakhla ", ASAE 7 (1906), PP. 95-96 .

- Donald M. Reid, "Indigenous Egyptology: The Decolonization of a Profession?," Journal of the American Oriental Society, Vol. 105, No. 2 (Apr. - Jun., 1985), PP. 233-246.

- Hassan Effendi Hosni, "Rapport sur une fouille Exècutèe dans le Desert Arabique àL' Est d'Atfih', ASAE 12 (1912), PP 51-56.

- Howard carter," Report on General work done in the southern inspectorate", ASAE 4 (1903), PP.43-50.

- Mohammed Effendi Chabân " Sur une nécropole de la VI dynastie, à Koçeir el-Amarna : Rapport de Mohammed effendi Chabân", ASAE 3 (1902), PP. 250 - 258.
$211-223$.

(1912) ,PP. $69-75$.

- Mr. Dow Covington, "Report on A summary exploration of Wady El kittar ", ASAE 9 (1908), PP.97-104.

- The Egyptian Supreme Council of Antiquities and the French Institute of Oriental Archaeology, The Cachette of Karnak: A Research Project on Georges Legrain's Discoveries between 1903 and 1907 , www.ifao.egnet.net/bases/cachette.

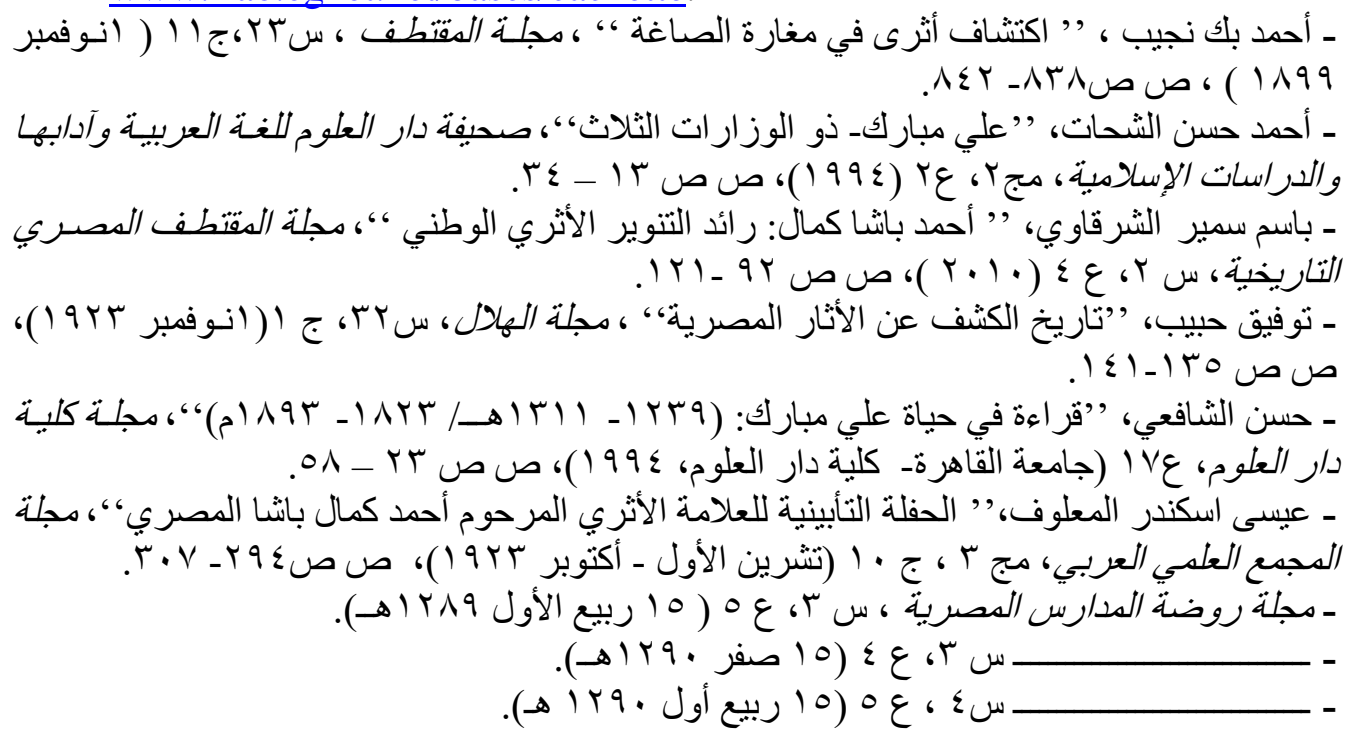


قســم الكتـب: مـدارس ملكيـة و مكاتـب خيريـة، س ع ، عه ا (10 شـعبان

. (ه 1 ( 9 .

ـ محمد زكريا عناني، ', التعريف و النقد: روضة المدارس نشأتها واتجاهاتها الأدبية و العلمية ، ، مجلـة

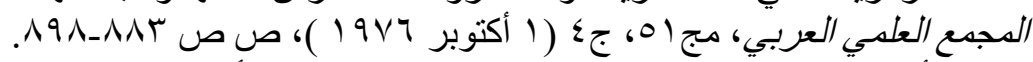

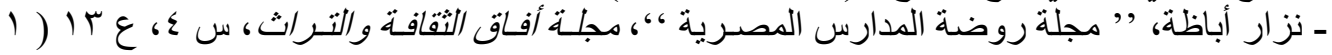

\section{c- Foreign References}

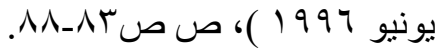

- Adam Mestyan, Arab Patriotism: The Ideology and Culture of Power in Late Ottoman Egypt (Princeton: University Press, 2017).

- Alan Henderson Gardiner, Egypt of the Pharaohs: An Introduction (Oxford: University Press, 1961).

- Appleton's' Annual Cyclopedia and Register of Important Events of the year 1894: Embracing Political, Military, and Ecclesiastical Affairs; Public Documents; Biography ,Statistics, Commerce, Finance, Literature ,science, Agriculture, and Mechanical Industry, Vol. XIX, (New York: D. Appleton and company, 72 Fifth Avenue , 1895 ).

- Arthur Goldschmidt Jr, Historical Dictionary of Egypt (Lanham, Maryland: Scarecrow Press, 2013).

- Charles Henry and Stanley Davis (ed.), Biblia Devoted to Biblical Archaeology and Oriental Research, April,1892- March1893 , Vol. V,( U.S.A: Meriden, conn,1893).

- Donald Malcolm Reid, Whose Pharaohs?: Archaeology, Museums, and Egyptian National Identity from Napoleon to World War I ( California: University Press, 2002).

- Contesting Antiquity in Egypt:

Archaeologies, Museums, and the Struggle for Identities from World War I to Nasser (Cairo: American University Press, 2015).

- Gamal El-Din El-Shayyal , A history of Egyptian Historiography in the nineteenth century ( Alexandria: faculty of Arts , N.15, 1962).

- Gouvernement Égyptien, Rapports Sur La Marche Du service des Antiquites de 1899 à 1910 (Le Caire Imprimerie Nationale ,1912).

- $\quad$ I.M. N. Al-Jubouri, Islamic Thought: From Mohammed to September 11, 2001 (U.S.A: Xlibris Corporation, 2010).

- J. Brugman, An Introduction to the History of Modern Arabic Literature in Egypt (Leiden: E. J. BRILL, 1984).

- Jill Kamil , Labib Habachi: The Life and legacy of an Egyptologist ( Cairo; American University Press, 2007).

- M. Naville, et.al , Special Extra Report: The season's work at Ahnas and Beni Hasan , 1890-1891, (London: Gilbert of Rivington, Limited, 1891 ). 
- Margarita diaz- Andreu, A world history of nineteenth century Archaeology: Nationalism, colonialism, and the past, (Oxford: University Press, 2007).

- Matt Cardin, Mummies around the World: An Encyclopedia of Mummies in History, Religion, and Popular Culture: An Encyclopedia of Mummies in History, Religion, and Popular Culture (Santa Barbara, California: ABC-CLIO, 2015).

- Okasha El Daly, Egyptology: The Missing Millennium: Ancient Egypt in Medieval Arabic Writings (New York: Routledge, 2016).

- Royal Asiatic Society of Great Britain and Ireland, Journal of the Royal Asiatic Society of Great Britain and Ireland (Cambridge: University Press for the Royal Asiatic Society, 1895).

- Sally MacDonald, and Michael Rice, Consuming Ancient Egypt (California: Left Coast Press, 2003).

- Sir Ernest Alfred Wallis Budge, An Egyptian Hieroglyphic Dictionary: With an Index of English words, King list of Hieroglyphic Characters, Coptic and Semitic Alphabets, Vol. I (Cosimo, 2010).

- Sue H. D' Auria (ed.), Servant of Mut: studies in Honor of Richard A. Fazzini (Boston, Leiden: Brill, 2008).

- Victor Loret, les tombeaux de thoutmès III et d'Amènophis II: et la cacheite royale de Biban - el- Molouk ( le Cairo Imprimerie Nationale, 1899).

- Warren R. Dawson and Eric p. uphill, who was who in Egyptology (London: the Egypt Exploration society, 3 Doughty mews, Wcin 2Pg, 1995).

- Zahi Hawass, Hidden Treasures Of The Egyptian Museum: On Hundred Masterpieces from the Centennial Exhibition( Cairo: American University Press, 2002).

\section{d- Arabic References}

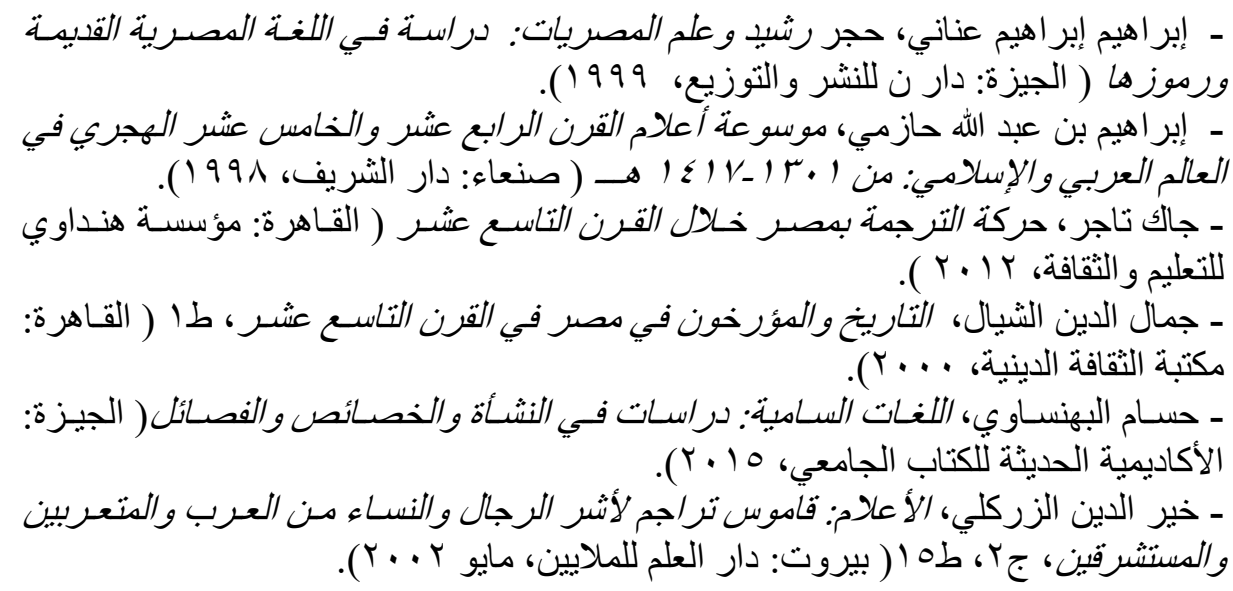


ـ رفاعة بدوي ر افع الطهطاوي، أنوار توفيق الجليل في أخبار مصر وتوثيق بنسي اسدعيل

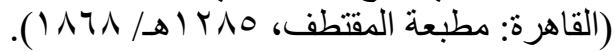
تلخيص الإبريز في تلخيص باربز ( القاهرة: مؤسسة هنداوي للتعليم

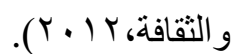
- زكى فهمى، صفوة العصر في تاريخ ورسوم مشاهير ورجال العصر من عهد ساكن الجنـان

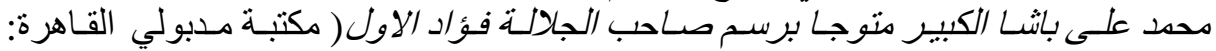

ـ عبد الرحمن زكى، دور التحف في مصر والجمعيات العلمبة ( القاهرة: 9 ؟ 9 1).

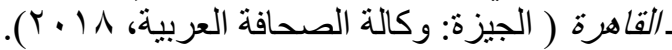

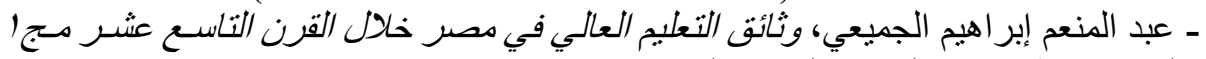

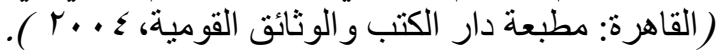

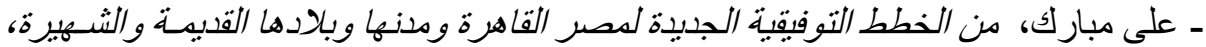

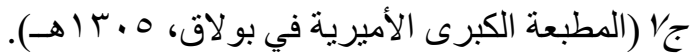

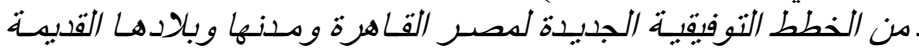

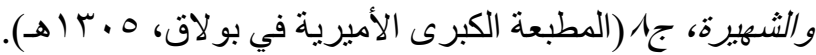

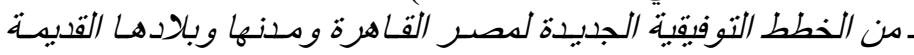

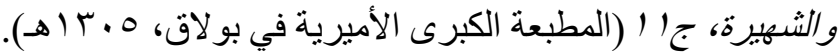

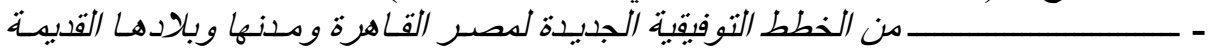

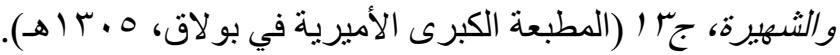

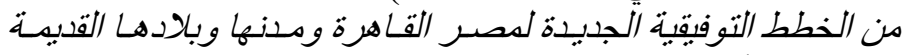

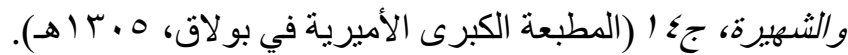

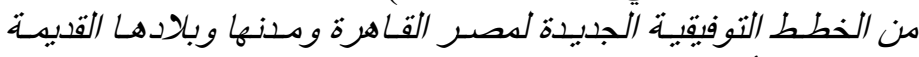

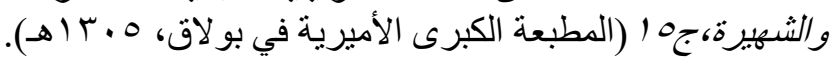

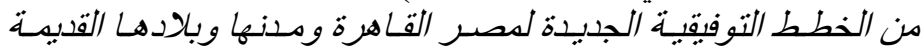

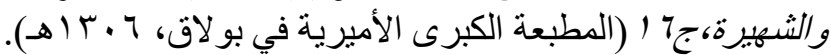

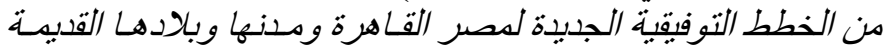

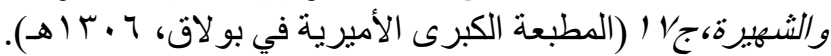

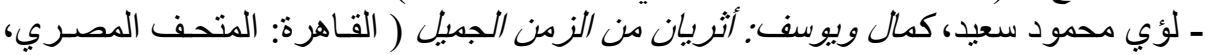
( - و وائل ابر اهيم الدسوقي، التاريخ الثقافي لمصر الحديثة: المؤسسات العلمبية والثقافية في القرن

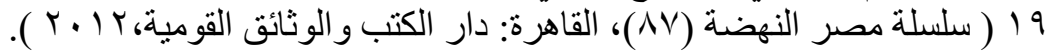

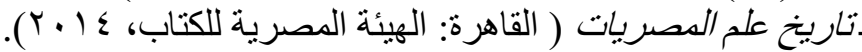

\section{E- University Thesis}

- Shadia Mahmoud, The development of Archaeological and Historical Museums in Egypt during the Nineteenth and twentieth centuries: Imperialism, Nationalism, Unesco Patronage, and Egyptian Museology Today (published PhD thesis ), the Graduate Faculty of Texas Tech University, 2012. 


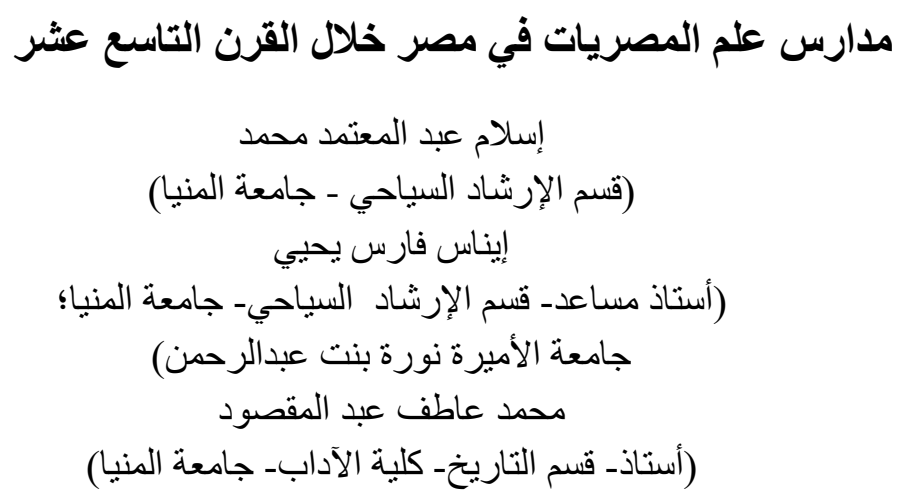

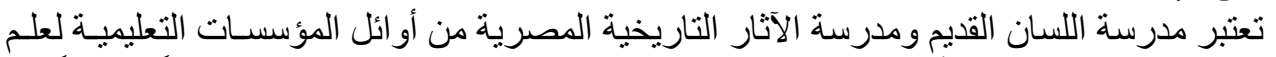

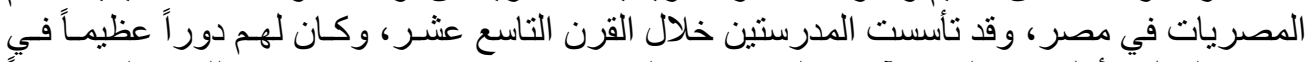

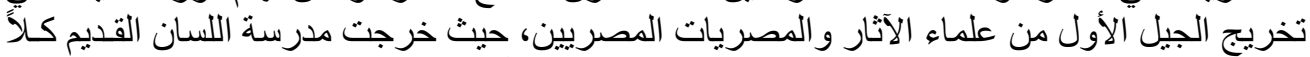

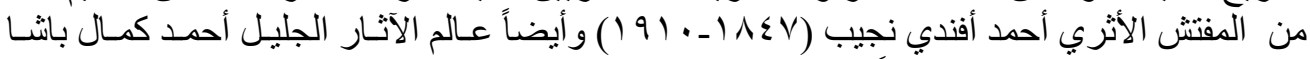

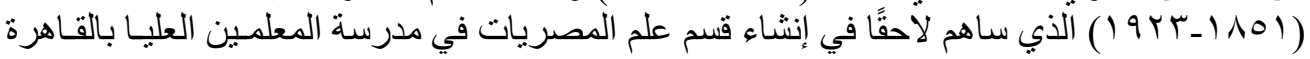

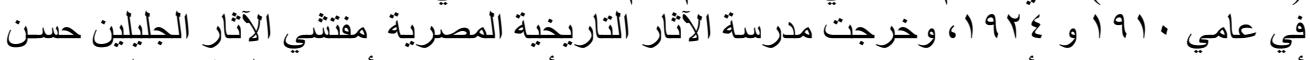

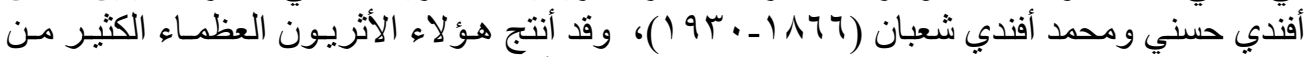
المؤلفات القيمة في علم المصريات وكذللك قاموا بالحفائر الأثرية.

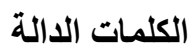

مدارس علم المصرياتـ أحمد كمـال باثــــ أحمد أفندي نجيبــ حسن أفندي حسنيـ محمد أفندي

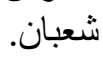

